\title{
Unexpectedly high ultrafine aerosol concentrations above East Antarctic sea ice
}

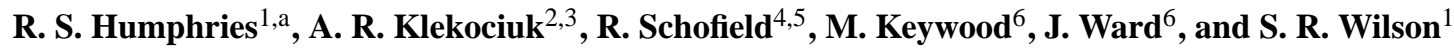 \\ ${ }^{1}$ Centre for Atmospheric Chemistry, University of Wollongong, Wollongong, Australia \\ ${ }^{2}$ Australian Antarctic Division, Hobart, Australia \\ ${ }^{3}$ Antarctic Climate and Ecosystems Cooperative Research Centre, Hobart, Australia \\ ${ }^{4}$ School of Earth Sciences, University of Melbourne, Melbourne, Australia \\ ${ }^{5}$ ARC Centre of Excellence for Climate System Science, University of New South Wales, Sydney, Australia \\ ${ }^{6}$ CSIRO Oceans and Atmosphere Business Unit, Aspendale, Australia \\ anow at: CSIRO Oceans and Atmosphere Business Unit, Aspendale, Australia
}

Correspondence to: R. S. Humphries (rsh615@uowmail.edu.au)

Received: 18 August 2015 - Published in Atmos. Chem. Phys. Discuss.: 27 October 2015

Revised: 3 February 2016 - Accepted: 4 February 2016 - Published: 25 February 2016

\begin{abstract}
Better characterisation of aerosol processes in pristine, natural environments, such as Antarctica, have recently been shown to lead to the largest reduction in uncertainties in our understanding of radiative forcing. Our understanding of aerosols in the Antarctic region is currently based on measurements that are often limited to boundary layer air masses at spatially sparse coastal and continental research stations, with only a handful of studies in the vast sea-ice region. In this paper, the first observational study of sub-micron aerosols in the East Antarctic sea ice region is presented. Measurements were conducted aboard the icebreaker $\mathrm{Au}$ rora Australis in spring 2012 and found that boundary layer condensation nuclei $\left(\mathrm{CN}_{3}\right)$ concentrations exhibited a fivefold increase moving across the polar front, with mean polar cell concentrations of $1130 \mathrm{~cm}^{-3}$ - higher than any observed elsewhere in the Antarctic and Southern Ocean region. The absence of evidence for aerosol growth suggested that nucleation was unlikely to be local. Air parcel trajectories indicated significant influence from the free troposphere above the Antarctic continent, implicating this as the likely nucleation region for surface aerosol, a similar conclusion to previous Antarctic aerosol studies. The highest aerosol concentrations were found to correlate with low-pressure systems, suggesting that the passage of cyclones provided an accelerated pathway, delivering air masses quickly from the free troposphere to the surface. After descent from the Antarctic free troposphere, trajectories suggest that sea-ice boundary
\end{abstract}

layer air masses travelled equatorward into the low-albedo Southern Ocean region, transporting with them emissions and these aerosol nuclei which, after growth, may potentially impact on the region's radiative balance. The high aerosol concentrations and their transport pathways described here, could help reduce the discrepancy currently present between simulations and observations of cloud and aerosol over the Southern Ocean.

\section{Introduction}

Reconciling the radiation budget over the Southern Ocean poses one of the greatest challenges for current climate models (Shindell et al., 2013; Pierce and Adams, 2006). State-ofthe-art models, compared in the international Atmospheric Chemistry and Climate Model Intercomparison Project (ACCMIP), significantly underpredict the aerosol optical depth (AOD) in the Southern Ocean (Shindell et al., 2013), suggesting a missing source of aerosols in the region. Given the coupling between aerosol and cloud properties, misrepresenting the AOD within models affects our representation of both the physics and chemistry of the atmosphere in the Southern Ocean region. A recent study by Carslaw et al. (2013) found that the biggest gains in reducing the discrepancy between global models and measurements would be achieved through 
the study of natural aerosols in environments with negligible anthropogenic influence.

The hostile marine and sea-ice environment of the Southern Ocean make measurements in this region difficult. The dearth of observations results in a poor characterisation of environmental parameters, including aerosol and cloud properties. Current knowledge suggests that the aerosol loading of this pristine area is made up primarily of sea salt and secondary inorganic aerosols (e.g. Asmi et al., 2010, and references within). The spatially sparse aerosol studies in the Antarctic and Southern Ocean region have focused primarily on these aerosols, and often miss the difficult-to-measure ultrafine aerosols, which are recently formed from gas-toparticle conversion and dwell in the size range of one to tens of nanometres (ultrafine aerosols are generally defined as those with diameters below $100 \mathrm{~nm}$ ). Aerosols in this size range are not yet large enough to effectively interact with radiation, making measurements using current-generation remote sensing technologies, such as satellites (which have the advantage of spatial coverage), near impossible. Measurements utilising in situ technologies, however, have been able to measure ultrafine aerosols down to $3 \mathrm{~nm}$ for over a decade, with further improvements in size range (down to $0.5 \mathrm{~nm}$ ) occurring in recent years (Kulmala et al., 2012). Investigations into the chemistry of ultrafine aerosols over the Southern Ocean then, can only occur through in situ measurements, which due to logistics are expensive and rare.

Due to these constraints, regular measurements are spatially limited, being restricted to mid-latitude stations on continents surrounding the Southern Ocean (e.g. Cape Grim, Australia), stations on sub-Antarctic islands (e.g. Macquarie Island) or Antarctic stations (e.g. Syowa Station). Short-term measurement campaigns are also rare, with only one major Southern Ocean focused aerosol campaign, the First Aerosol Characterisation Experiment (e.g. Quinn et al., 1998). Measurements in the sea ice are particularly rare, given the difficulties posed by the dynamic environment for longterm measurements and the need for icebreakers for any campaign-based measurements. Consequently, only a handful of aerosol measurements have been published for the entire Antarctic sea ice region, all occurring in the West Antarctic sector (Davison et al., 1996; O’Dowd et al., 1997; Atkinson et al., 2012). There have been no measurements reported for the vast East Antarctic sea-ice region, and consequently, our knowledge of aerosol loading here relies solely on model studies which, at most, have been validated using data from nearby continental stations which may not be representative of the sea ice region.

The current data set, obtained as part of a major marine science voyage, consists of measurements of number concentrations of ultrafine aerosol in the Antarctic sea ice. This data set provides a rare opportunity for understanding natural aerosol processes in an environment almost free of anthropogenic influences, to gain further insights into the identity of a missing aerosol source in the region and to help reconcile the differences between models and measurements.

\section{Methods}

Full details of measurements and their platform have been outlined in detail in an earlier publication (Humphries et al., 2015). Consequently, only a brief overview is given here.

Measurements were made aboard Australia's icebreaker, Aurora Australis, as part of the second Sea Ice Physics and Ecosystems eXperiment (SIPEXII) from 14 September to 11 November 2012. The voyage involved 52 days in the East Antarctic pack ice (south of $61.5^{\circ} \mathrm{S}$, between 112 and $122^{\circ} \mathrm{E}$ ) during which the ship traversed between eight ice floes that were used as temporary research stations (1-5-day periods anchored to the drifting ice floe). Various environmental and voyage parameters (e.g. meteorology and ship location and speed) were measured continually as part of the regular operation of the ship and are available through Reeve (2013).

In situ aerosol number concentrations (Humphries et al., 2014) were measured using two condensation particle counters (CPCs) at $1 \mathrm{~s}$ time resolution while in the pack ice, between 23 September and 25 October. Measurements of two different size ranges were made: particles with diameters larger than $3 \mathrm{~nm}\left(\mathrm{CN}_{3}\right.$; Model $3025 \mathrm{~A}$, TSI, Shoreview, MN, USA), and those larger than $10 \mathrm{~nm}\left(\mathrm{CN}_{10}\right.$; Model 3772 , TSI, Shoreview, MN, USA). The difference between $\mathrm{CN}_{3}$ and $\mathrm{CN}_{10}$ can be used to characterise the number concentration of nanoparticles $\left(3-10 \mathrm{~nm} ; \mathrm{CN}_{3-10}\right)$ which have recently formed from gas-to-particle conversion. Appropriate data filtering utilising in situ wind and ozone data (see Humphries et al., 2015, for details) was performed to remove the influence of ship exhaust and to obtain a data set that reflected the background ambient atmosphere. Operational and logistical constraints meant that a more comprehensive aerosol measurement suite was unable to be deployed during this voyage. Additionally, due to unforeseen operational delays, supplies of the working fluid (1-butanol) for CPCs were exhausted prior to departure from the sea-ice region, preventing measurements during the return northward transect.

Full details of the sampling system and data filtering are given in Humphries et al. (2015), however it is important to note that a significant fraction (up to $70 \%$ for $3 \mathrm{~nm}$ particles) of $\mathrm{CN}_{3-10}$ was lost in the $21.7 \mathrm{~m}$ long sample tube (used for logistical reasons) despite the high flow rates utilised. Appendix Fig. A1 shows the inlet efficiencies calculated experimentally (relative to a reference inlet) and using theoretical calculators - e.g. von der Weiden et al. (2009), see Humphries (2015) for details. Due to the large uncertainties associated with inlet efficiency calibrations in this size range, it was decided that a single inlet efficiency factor of 0.88 (determined from bootstrap sampling of experimentally derived data) be used across the entire size range. Most studies of 
aerosol loading do not describe any corrections for size varying inlet efficiencies, particularly in the smallest of these size ranges where uncertainties are high. Consequently, the substantially lower inlet efficiencies expected in the sub- $10 \mathrm{~nm}$ size range measured here (Appendix Fig. A1) are not applied to our data, and it is noted therefore that the numbers presented in this paper represent only the lower bound of ambient number concentrations, which could in reality be up to 3 times higher if theoretically estimated losses are correct.

A number of trace gases were also measured during the voyage. These were used for data filtering (e.g. ozone; Schofield et al., 2014) and other aspects of the project and details have been included in Humphries et al. (2015).

\section{Trajectory analysis}

The HYSPLIT (HYbrid Single-Particle Lagrangian Integrated Trajectory) model (Draxler and Hess, 1998) was used to calculate air parcel trajectories (Schofield and Klekociuk, 2014). In this study, HYSPLIT was used to calculate back trajectories in order to evaluate source locations, while forward trajectories were used to understand spatial impacts of measured constituents.

Trajectories were calculated in repetition using three different meteorological reanalysis data sets: ERA Interim reanalysis (Dee et al., 2011), the Global Data Assimilation System (GDAS) analysis (Kanamitsu, 1989) and the National Center for Environmental Prediction/National Center for Atmospheric Research (NCEP/NCAR) reanalysis (Kistler et al., 2001). The model was set up to utilise $1.5^{\circ}$ horizontal resolution reanalysis data and calculations were performed using vertical motion mode. An increased resolution of $0.75^{\circ}$ was tested in a sensitivity study and resulting circulation patterns were unaffected. Calculations utilised surface invariant geopotential, surface $10 \mathrm{~m}$ horizontal $(U$ and $V$ ) winds, $2 \mathrm{~m}$ surface temperature, and $U, V, W$ (vertical wind), temperature and humidity, on pressure levels from 1000 to $100 \mathrm{hPa}$ (excluding $125 \mathrm{hPa}$ to adhere to host data download limits). Each trajectory calculation provided hourly threedimensional air parcel locations for a total time span of up to 5 days. Trajectories were initiated at the ship's location for every hour of the cruise at heights of $10 \mathrm{~m}$ (a.m.s.l.) and from 500 to $4000 \mathrm{~m}$ at $500 \mathrm{~m}$ intervals.

The uncertainty of trajectories at these high southern latitudes is a legitimate concern. Uncertainties are highest for trajectories started within the boundary layer; however, it was determined that those released at higher altitudes showed circulation patterns consistent with boundary layer releases. A thorough assessment of trajectory analyses has been performed and will be discussed in full in a future paper; however, a brief overview of those aspects relevant for this work are included in the Appendix.

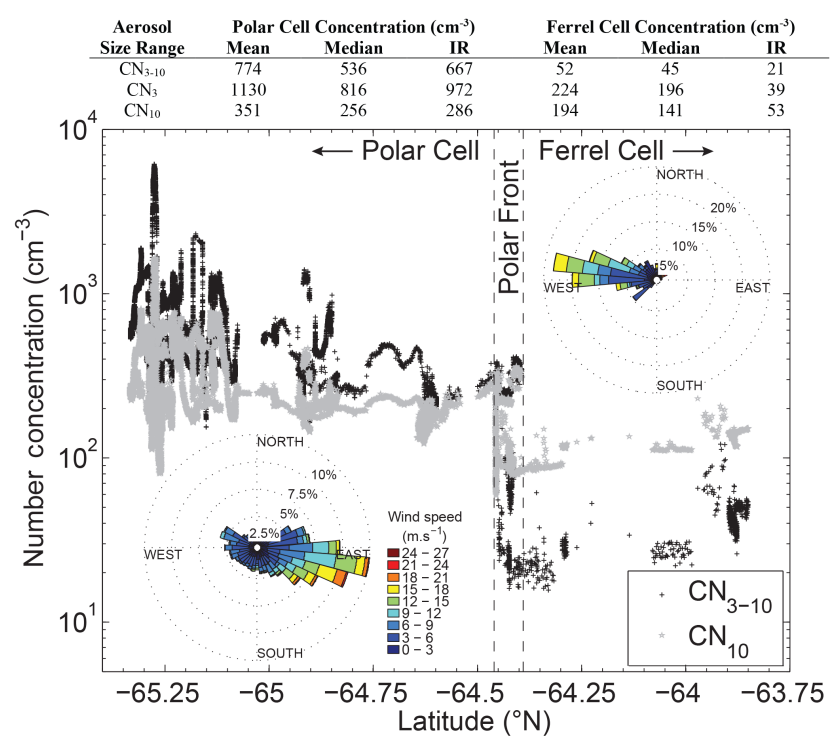

Figure 1. Thirty-two days of ship-based measurements of aerosol above the sea ice (south of the ice edge at $62^{\circ} \mathrm{S}$ ) show a sharp jump in aerosol number concentration moving south across the polar front. Wind roses, calculated using in situ data from either side of the front confirm the expected easterly and westerly patterns of the polar and Ferrel cells respectively. Aerosol statistics (mean, median and the interquartile range (IR)) are given above.

\section{Results}

Measured sub-micron particles were found to exhibit surprising features for this region. Number concentrations were observed to show a significant step change as the ship moved south in the pack ice. Figure 1 shows that this step change was most pronounced in the $\mathrm{CN}_{3-10}$ size range, with an order of magnitude increase, while $\mathrm{CN}_{10}$ concentrations doubled. This step transition occurred between 64.39 and $64.46^{\circ} \mathrm{S}$ on the 29 September, coinciding with a period during which the ship was drifting west with the pack ice during Ice Station 1, and minimal latitudinal movement was occurring (Fig. A3). It is likely that the poorly defined latitudinal boundary observed in Fig. 1 is a result of drifting west across a zonally asymmetric atmospheric boundary at that location and time.

It is postulated that this step change was a result of moving between the two major circulation cells influencing the region, the polar and Ferrel cells, and whose boundary, the polar front, lies at approximately this latitude. This hypothesis was tested by analysing meteorological wind data obtained during the voyage and comparing to the expected surface winds in each cell. Wind roses were constructed utilising two subsets of the data, those south of the transition latitude, and those north. The resulting wind roses, shown as insets in Fig. 1, showed a significant difference between the two regions, with the southern data set showing predominant easterlies, as would be expected in the polar cell, while the northern data set showed prevailing westerlies, consistent with 
Ferrel cell circulation. Interestingly, although the oceanic polar front was much further north of these latitudes (calculated as in Dong et al., 2006), sea surface temperatures measured during the sea-ice portion of the voyage showed a small but significant change across the same boundary, moving from $-1.75 \pm 0.02^{\circ} \mathrm{C}$ (median \pm median absolute deviation) north of the boundary, to $-1.85 \pm 0.01{ }^{\circ} \mathrm{C}$ to the south (see Appendix Fig. A2). These data support the inference that the measurement platform moved from the Ferrel cell, where low aerosol concentrations are observed, across the transition of the polar front, into the polar cell, where enhanced concentrations were present.

Statistics of aerosol number concentrations in the various size ranges are presented in detail in the table included in Fig. 1. Sub-micron aerosol number concentrations measured in the Ferrel cell during this voyage were about half of those observed during other measurements in the Southern Ocean marine boundary layer (MBL, e.g. Brechtel et al., 1998; Wiedensohlet et al., 1997), with median $\mathrm{CN}_{3}$ concentrations of $195 \mathrm{~cm}^{-3}$ (mean, $\bar{x}=224 \mathrm{~cm}^{-3}$ ). It is important to note that measurements in the Ferrel cell portion of the voyage exhibit significantly reduced ocean swell compared to that expected in other Southern Ocean measurements, and only represent 6 days of measurements, so may not be fully representative of southern Ferrel cell number concentrations. In contrast, measurements within the polar cell lasted 26 days, and resulted in median $\mathrm{CN}_{3}$ concentrations of $816 \mathrm{~cm}^{-3}\left(\bar{x}=1130 \mathrm{~cm}^{-3}\right)$. Except for one new particle formation event which resulted in measured $\mathrm{CN}_{3}$ concentrations over $7500 \mathrm{~cm}^{-3}$ (described in detail in Humphries et al., 2015), background aerosol $\mathrm{CN}_{3}$ concentrations generally ranged between 500 and $2000 \mathrm{~cm}^{-3}$, with not infrequent periods above $2600 \mathrm{~cm}^{-3}$. It is important to note that due to the inability to accurately characterise inlet efficiencies for aerosol diameters below $10 \mathrm{~nm}$ (as mentioned earlier), the values reported here represent only lower bounds for ambient concentrations and could be up to 3 times higher.

Only a few other aerosol studies in the Antarctic pack ice have been reported in the literature (Davison et al., 1996; O’Dowd et al., 1997; Atkinson et al., 2012; Koponen et al., 2002), all occurring in the Weddell Sea of the Antarctic Peninsula. The measurements reported by Davison et al. (1996) occurred in the early summer (in comparison to the springtime measurements reported here) and found background $\mathrm{CN}_{3}$ to be $400-600 \mathrm{~cm}^{-3}$, with local new particle formation events responsible for short-term peaks up to $4000 \mathrm{~cm}^{-3}$. December measurements of O'Dowd et al. (1997) observed similar patterns, with $\mathrm{CN}_{3}$ concentrations remaining generally below $500 \mathrm{~cm}^{-3}$, and short-term peaks over $1000 \mathrm{~cm}^{-3}$ likely the result of particle formation events. A week of December measurements during a longitudinal transect in the Weddell Sea by Koponen et al. (2002) found a significant increase in nucleation mode particles compared to open ocean populations, with concentrations reaching close to $1000 \mathrm{~cm}^{-3}$ during short-term (order of hours) events. Dur- ing these events, size distribution data showed enhanced nucleation mode number concentrations with mode diameters typically between 5 and $15 \mathrm{~nm}$, and almost never below $5 \mathrm{~nm}$. This, together with the absence of temporal changes in modal mean diameter, led the authors to suggest that nuclei were not formed in the MBL near the measurement site, but instead postulated the Antarctic free troposphere (AFT) as a likely source. More recent measurements in early summer by Belosi et al. (2012) on the Nansen Ice Sheet in the Ross Sea exhibited similar concentrations to those of Davison et al. (1996). In contrast, coastal measurements obtained between 1991 to 2009 at Neumayer Station (Weller et al., 2011, a coastal location) showed that daily average $\mathrm{CN}_{3}$ concentrations exhibited a seasonal cycle with a July minimum (at around $100 \mathrm{~cm}^{-3}$ ), an October peak of $350 \mathrm{~cm}^{-3}$ followed by an annual maximum in March of around $800 \mathrm{~cm}^{-3}$. Measurements at Aboa (Asmi et al., 2010; Koponen et al., 2003, coastal) showed January monthly averages that ranged between 370 and $640 \mathrm{~cm}^{-3}$, depending on the year. At South Pole (Park et al., 2004, continental), number concentrations in December ranged from 100 to $300 \mathrm{~cm}^{-3}$. $\mathrm{CN}_{3}$ data from Southern Ocean measurements showed average $( \pm$ standard deviation) number concentrations at Macquarie Island between late November and early December, during clean marine periods, and Antarctic influence, of $675 \pm 260$ and $571 \pm 124 \mathrm{~cm}^{-3}$, respectively (Brechtel et al., 1998). Measurements at Cape Grim Baseline Air Pollution Station (CGBAPS) show summer averages of $944 \pm 504 \mathrm{~cm}^{-3}$, similar to those observed in this springtime study, however measurements in spring at CGBAPS are substantially lower at $562 \pm 417 \mathrm{~cm}^{-3}$ (Jimi et al., 2007). There are numerous $\mathrm{CN}_{10}$ measurements reported in the literature for Antarctic stations, all with median values below $275 \mathrm{~cm}^{-3}$, the highest of which are found at coastal stations (Kyrö et al., 2013; Järvinen et al., 2013; Hansen et al., 2009; Hara et al., 2011a). It is important to note that in the Antarctic region, $\mathrm{CN}_{3}$ concentrations show a small peak in spring, with an annual maximum in summer (e.g. Weller et al., 2011; Virkkula et al., 2009; Bigg et al., 1983).

Comparison of $\mathrm{CN}_{3}$ to $\mathrm{CN}_{10}$ in our data reveals an important feature of the measured aerosol record. Median $\mathrm{CN}_{10}$ concentrations in the Ferrel cell were $141 \mathrm{~cm}^{-3}(\bar{x}=$ $\left.193 \mathrm{~cm}^{-3}\right)$ compared to a $256 \mathrm{~cm}^{-3}\left(\bar{x}=351 \mathrm{~cm}^{-3}\right)$ in the polar cell. Comparison to $\mathrm{CN}_{3}$ data reveals that the size distribution of aerosol populations changed drastically between the two circulation cells. In the Ferrel cell, populations were found to be composed primarily $(80 \%)$ of particles larger than $10 \mathrm{~nm}$ diameter. In contrast, only $30 \%$ of the particles measured in the polar cell were larger than $10 \mathrm{~nm}$. This drastic increase in the influence of nanoparticles suggests that a strong local particle source was nearby. 

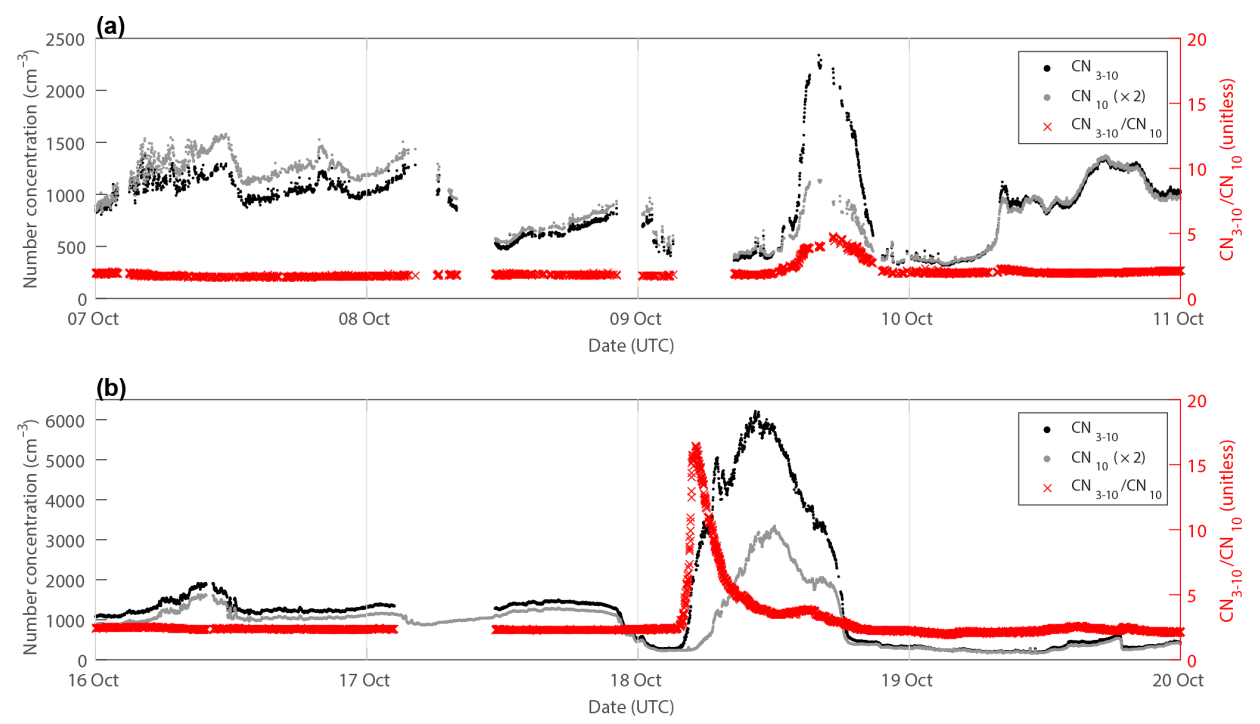

Figure 2. Four days of aerosol number concentrations in the two available size bins, $3-10 \mathrm{~nm}\left(\mathrm{CN}_{3}-10\right)$, and those larger than $10 \mathrm{~nm}\left(\mathrm{CN}_{10}\right)$, along with their ratio that helps to identify new particle formation and growth. (a) Four days representative of the data set show simultaneous variation in both size bins, and little variation in ratio data. (b) Similar to (a), except that it includes the only growth event that was observed during the voyage, included to demonstrate what growth would look like with the available data, showing a delay in variations between the two size bins. Note the change in scale of the left $y$ axis between the two plots.

\subsection{Aerosol growth}

Background $\mathrm{CN}_{3}$ concentrations observed during this voyage were found to be dominated $(70 \%)$ by particles in the $3-$ $10 \mathrm{~nm}$ size range. This high fraction would seem to suggest relatively recent nucleation, and as such, growth in these size ranges was likely to be observed.

Large fluctuations in $\mathrm{CN}$ data are often indicative of local new particle formation events. If local formation was occurring, it is unlikely that once particles grew beyond $3 \mathrm{~nm}$ (where they can be measured with the instruments deployed here) that growth beyond $10 \mathrm{~nm}$ would not occur. Where changes in both $\mathrm{CN}_{3-10}$ and $\mathrm{CN}_{10}$ data occur simultaneously, it can be assumed that the measured population is in a steady state - that is, the number of particles growing into the $\mathrm{CN}_{3-10}$ size bin equals the number leaving and entering the $\mathrm{CN}_{10}$ size range. This steady state is most easily achieved when this size flux is zero, as is the case when particles are not growing. If the changes in number concentration between the two sizes are delayed with respect to each other (of the order of minutes to hours), then it can be assumed that aerosol populations are changing in modal size. If there is no delay, the steady state exists, and aerosol populations are not likely to be growing.

Figure 2 shows two subsets of aerosol data that are representative of the aerosol data set. Both data sets show significant fluctuations in the background aerosol concentration which may be a result of local particle formation. Assessment of the delay between changes in the two size bins reveals that, except for the significant particle formation event observed on the 18 October (Humphries et al., 2015), there were no periods where delays were observed in the data set. The absence of growth signatures suggests that background aerosol populations were in the steady state, and were most likely not growing.

Changes in the $\mathrm{CN}_{3-10} / \mathrm{CN}_{10}$ ratio have been shown previously to be a good indicator of new particle formation when limited measurements are available (Warren and Seinfeld, 1985). As observed in Fig. 2, this ratio increases significantly during a particle formation event to values well above 10 . During all other periods, this ratio value did not increase above 4.8 (9 October, described further in the Appendix), and had a mean ( \pm standard deviation) of $1.8 \pm 0.6$. This strengthens the idea that the dominant background concentrations, while having a significant sub- $10 \mathrm{~nm}$ fraction, were not the result of local new particle formation.

The most probable explanation is that the significant background aerosol population was not formed locally, but rather nucleated elsewhere before being transported to the measurement region. To investigate the source regions contributing to this population, air-mass histories were assessed by the use of backward trajectories.

\subsection{Air-mass history}

Hourly backward trajectories were calculated along the ship track throughout the voyage. It is important to note that at the high latitudes of the Antarctic, the meteorological reanalysis data sets upon which trajectories are calculated rely on relatively sparse meteorological measurements. Conse- 
quently, these data sets, along with the trajectories, contain high uncertainties. Because of this, trajectories were limited to a maximum of 5 days, and often to just 3 , similar to numerous other studies in the region (e.g. Stohl and Sodemann, 2010; Kottmeier and Fay, 1998; Helsen et al., 2006).

Results from backward trajectories ending at locations north of the polar front latitudes identified from aerosol data, found that air masses generally came from the northwest, remaining within the MBL for the duration of the period calculated. Trajectories initiated from locations south of these polar front latitudes (corresponding to the highest aerosol loading in this data set) showed that, in general, air had come from the east, travelling within the sea-ice boundary layer for an average of $36 \mathrm{~h}$ before arrival at the ship. Prior to this, these air masses were consistently found to have travelled from the south and descended from the mid-upper AFT, generally from above $2 \mathrm{~km}$ over the continent's surface. This pattern, of Southern Ocean MBL influence north of the polar front, and mid-upper AFT influence south of the polar front, was consistent throughout the voyage.

Further assessment of trajectories was performed by taking the average of all the trajectories calculated along the voyage path, then separating them into their dimensional (temporal and latitudinal, longitudinal, and vertical spatial) components and viewing as a function of altitude and latitude. Figure 3 shows the resulting vertical wind plot after averaging 5-day trajectories. A surprising downward flow that extends from the mid-upper AFT at around $75^{\circ} \mathrm{S}$, reaching the surface at around $68^{\circ} \mathrm{S}\left(64-72^{\circ} \mathrm{S}\right)$ is observed. This pattern is independent of input meteorology and starting height and also dominates the results based on 10-day trajectories (Appendix Fig. A4). The northernmost edge of this flow corresponds well with the latitude at which the step change in the aerosol record is observed.

To determine whether these circulation features were consistent throughout the measurement period at these latitudes, 3-day backward trajectories were calculated with endpoints falling along the same longitude, $120^{\circ} \mathrm{E}$, but at latitudes just north of the polar front $\left(60.0^{\circ} \mathrm{S}\right)$, just south (and therefore within the influence of the downward flow; $65.5^{\circ}$ ), and at a latitude south of the influence of the downward flow, representative of a continental location $\left(73.0^{\circ} \mathrm{S}\right)$. Results from these calculations, a sample of which is shown in Fig. 4, confirm the patterns described above, with $60.0^{\circ} \mathrm{S}$ trajectories predominantly influenced from MBL air masses from the northwest and $65.5^{\circ} \mathrm{S}$ air masses coming from the mid-upper AFT. Trajectories calculated from $73.0^{\circ} \mathrm{S}$ show a consistent pattern of southerly surface influence, with air masses rarely extending above $500 \mathrm{~m}$ a.g.l. (compared to over 2 and up to $5 \mathrm{~km}$ for $65.5^{\circ} \mathrm{S}$ air masses), consistent with katabatic winds.

These trajectories suggest two important points. Firstly, the high aerosol number concentrations observed during the southern portion of the voyage are likely to have been sourced in the AFT, rather than the other possibility, the MBL. Although we cannot eliminate the possibility of MBL

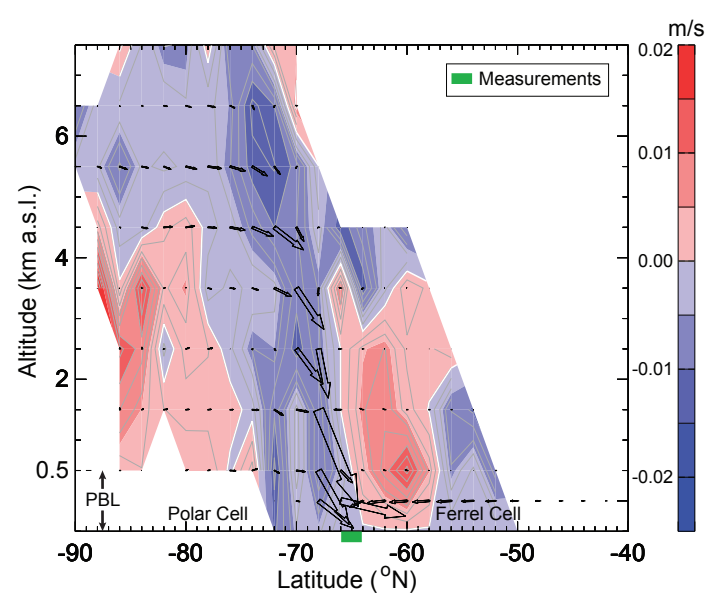

Figure 3. Vertical component of trajectory calculations constructed from a frequency analysis (number of times a trajectory passes through a grid box) of 5-day back trajectories. Trajectories were released at $10 \mathrm{~m}$ height (a.s.1.) from the marked (green) measurement locations every hour of the sea-ice leg of the voyage ( $>1100$ trajectories). Free-tropospheric air is observed to reach the sea-ice surface via a well-defined downward flow, just south of the rising polar front. Colour contours describe the mean vertical wind, while overlying vectors show two-dimensional movement weighted by the number of points at each location. Note that the lowest section of the $y$ axis is expanded to show the planetary boundary layer (PBL) in more detail, and the continent is smeared because of longitudinal averaging.

formation upwind of the measurement location, a number of factors make it unlikely: (1) the long duration of elevated particle concentrations (order of days) suggests a large homogeneous source, rather than local surface formation; (2) the absence of growth in the data set; (3) it would be unlikely not to observe local formation occurring while on a measurement platform that is moving through the MBL source region; and (4) previous measurements (e.g. Koponen et al., 2002) have observed frequent nucleation populations where mode diameters were almost never below $5 \mathrm{~nm}$, suggesting that local formation is unlikely. Consequently, the AFT is significantly more plausible as a source region. Numerous studies have previously observed enhanced aerosol number concentrations in the AFT (e.g. Ito et al., 1986; Osada et al., 2006; Hara et al., 2011b), and even more have suggested it as the dominant source region of Antarctic aerosol (Ito, 1989, 1993, 1995; Virkkula et al., 2009; Asmi et al., 2010; Järvinen et al., 2013; Koponen et al., 2003). We speculate that the absence of signs of growth in the data presented in this study could be a result of condensational growth halting, possibly due to exhaustion of the precursor source, prior to reaching the measurement location.

Secondly, trajectory data suggest that the sea-ice region of East Antarctica is atmospherically distinct from the latitudinally adjacent regions. This is also supported by the contrasting concentrations between the regions, with low concentra- 
Backward trajectories ending at 0000 UTC 13 Oct 2012

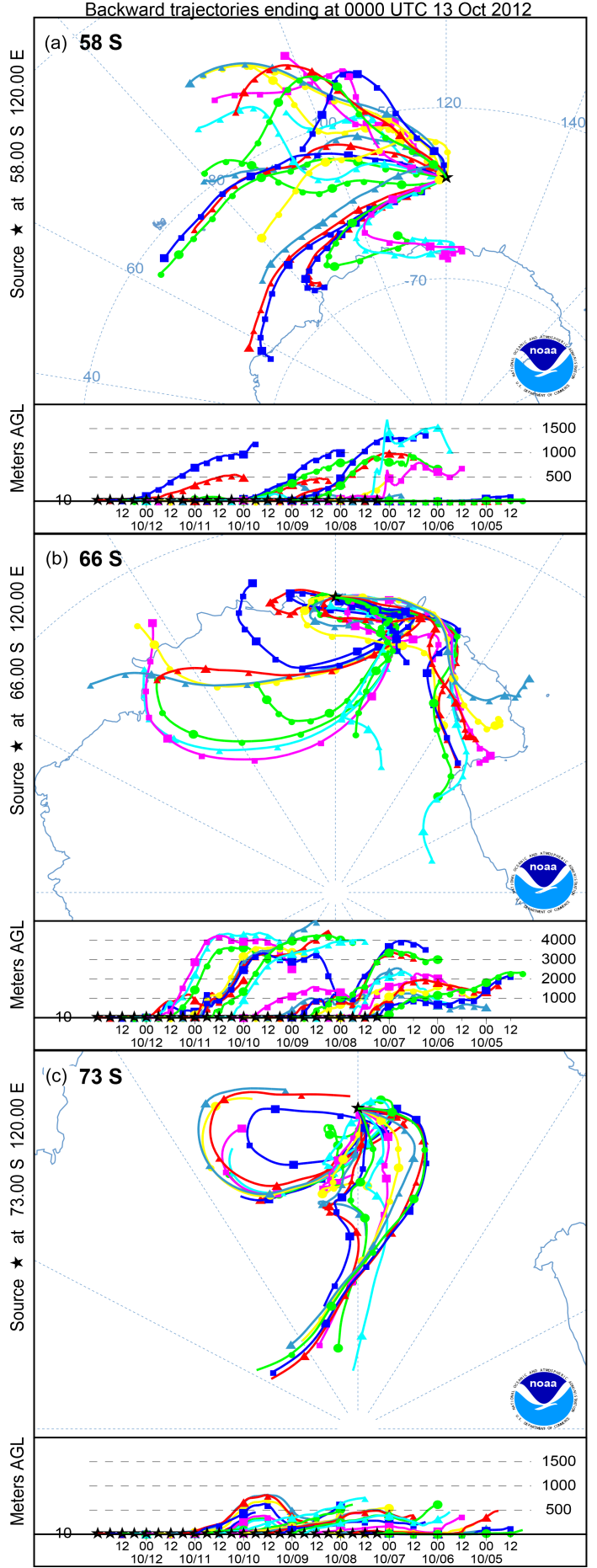

Figure 4. Three-day $(72 \mathrm{~h}$ ) back trajectories calculated from $10 \mathrm{~m}$ above mean sea level using the HYSPLIT model with GDAS input meteorology for a 7-day period ending at midnight on 13 October 2012. All trajectories have endpoints at $120^{\circ} \mathrm{E}$, and differing latitudes: (a) $\left(58.0^{\circ} \mathrm{S}\right),(\mathbf{b})\left(66^{\circ} \mathrm{S}\right)$ and $(\mathbf{c})\left(73.0^{\circ} \mathrm{S}\right)$. Changes in colour help identify different trajectory ending times. tions observed in our data (Fig. 1) and in the literature (e.g. Brechtel et al., 1998; Wiedensohlet et al., 1997) for locations north of the polar front, as well as those observed at other permanent research stations on the Antarctic coast and continent, as discussed above. This suggests that existing measurements on the continent or in the Southern Ocean may not be representative of the region as a whole.

\subsection{Variations in aerosol number concentrations}

Background aerosol number concentrations varied considerably throughout the voyage, particularly within the polar cell. As observed in Fig. 2a, background number concentrations varied by over $1000 \mathrm{~cm}^{-3}$ on an hourly-daily timescale. These variations were investigated by comparison with meteorological, in situ gas composition, and trajectory data. No visible relationship between variations in aerosol number concentrations were found with respect to gas composition (e.g. $\mathrm{O}_{3}$, total gaseous mercury or halogenated volatile organic compounds) or meteorological parameters (e.g. relative humidity) other than atmospheric pressure. These correlations with atmospheric pressure suggest the possible influence of the passage of cyclones.

The measurement period was characterised by eight major pressure systems as identified by in situ meteorological data. Table 1 summarises the in situ meteorological conditions present during these periods, together with coincident aerosol number concentrations. These periods were confirmed as either high- or low-pressure systems by meteorological models run as part of the voyage. In general, lowpressure systems were associated with the highest aerosol concentrations, $\mathrm{CN}_{3}$ generally reaching over $2000 \mathrm{~cm}^{-3}$, while high-pressure systems coincided with low concentrations, well below $1000 \mathrm{~cm}^{-3}$. This relationship between pressure and aerosol number concentration is shown more clearly in Fig. 5, where a significant negative correlation is observed, with an $R^{2}$ value of 0.41 . A positive correlation is also apparent with potential temperature (not shown), a trend that seems to be driven primarily by measured pressure.

To assess this idea further, back trajectories were compared between periods which experienced high and low pressure (and consequently aerosol number concentration). In this analysis, 5-day trajectories were calculated with endpoints at the measurement location throughout the voyage, but for two distinct pressure regimes: those when the air pressure at the trajectory endpoint was in the lowest 20th percentile (coinciding to pressures below $969.8 \mathrm{hPa}$ ); and those in the highest 20th percentile (pressures above $989.8 \mathrm{hPa}$ ). Results from this analysis are shown in Fig. 6. The spatial frequency component of the trajectories, shown in panels a and b, show distinctly different influence between the two scenarios. During low-pressure periods, air-mass influence from the upper troposphere increases substantially compared to the high-pressure case. During the high-pressure periods, dominant influence remains below around $3 \mathrm{~km}$ altitude. Interest- 
Table 1. Summary of meteorological parameters and corresponding $\mathrm{CN}_{3}$ number concentrations. Low aerosol concentrations (top four rows) correspond to calm conditions while high aerosol conditions (lower four rows) correspond to parameters that suggest cyclone activity.

\begin{tabular}{|c|c|c|c|c|}
\hline Date & Location & Atm. pressure $(\mathrm{hPa})$ & Wind speed $\left(\mathrm{ms}^{-1}\right)$ & $\mathrm{CN}_{3}\left(\mathrm{~cm}^{-3}\right)$ \\
\hline $4-6$ Oct & $64.9-65.0^{\circ} \mathrm{S}, 120.8-121.7^{\circ} \mathrm{E}$ & $\sim 975$, steady & $<10$ & $<1000$ \\
\hline $11-14$ Oct & $65.2-65.3^{\circ} \mathrm{S}, 119.9-120.3^{\circ} \mathrm{E}$ & $\sim 980$, slowly increasing & $<10$ & $<1000$ \\
\hline 15 Oct & $65.3^{\circ} \mathrm{S}$ steady, $119.7-120.0^{\circ} \mathrm{E}$ & $<990$, ridge & $<15$ & $<1000$ \\
\hline 19-21 Oct & $65.3^{\circ} \mathrm{S}$ steady, $118.9-119.1^{\circ} \mathrm{E}$ & 1000-980, decreasing & $<15$ & $<900$ \\
\hline $7-8$ Oct & $65.1^{\circ} \mathrm{S}$ steady, $120.6-121.4^{\circ} \mathrm{E}$ & $<960$, trough & $>20$ & $1400-2100$ \\
\hline 10 Oct & $65.2^{\circ} \mathrm{S}$ steady, $120.3-120.8^{\circ} \mathrm{E}$ & $<962$, trough & $>20$ & $1200-2000$ \\
\hline $16-17$ Oct & $65.3^{\circ} \mathrm{S}$ steady, $119.1-119.7^{\circ} \mathrm{E}$ & $<968$, trough & $>15$ & $1500-2700$ \\
\hline $22-23$ Oct & $65.1-65.3^{\circ} \mathrm{S}, 118.3-119.0^{\circ} \mathrm{E}$ & $<970$, trough & $>20$ & $900-1900$ \\
\hline
\end{tabular}

The 9 October exhibited an unusually high aerosol number concentration and consequently it has been omitted from this table. This event is described in detail in the Appendix.

A local new particle formation event occurred on 18 October and has been excluded from this analysis. This event is described in detail in Humphries et al. (2015).

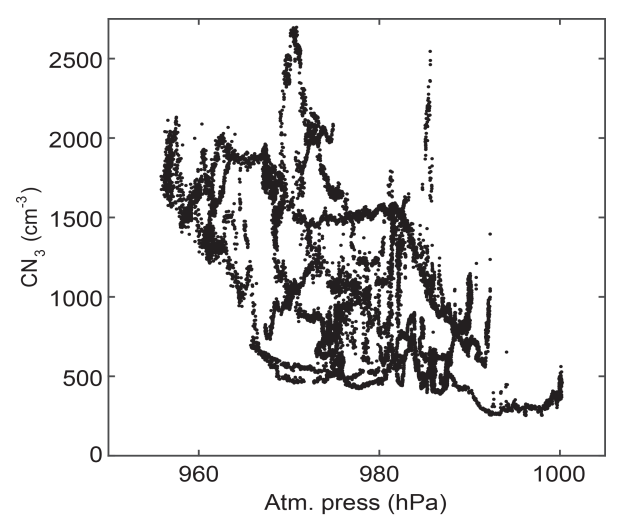

Figure 5. Measured atmospheric surface pressure (hPa) vs. $\mathrm{CN}_{3}$ $\left(\mathrm{cm}^{-3}\right)$ for the period of 4-25 October (prior to this period, influence came primarily from the northwest marine boundary layer). Short-term enhancement events on the 9 and 18 October are removed.

ingly, the well-defined downward flow is apparent in both scenarios, however the depth of its penetration into the upper troposphere differs significantly. This is confirmed by an analysis of the exposure of trajectories to different levels in the atmosphere (panels c and d). The high-pressure scenarios show peak influence (above the surface layer) in the $1-2 \mathrm{~km}$ altitude layer, with a rapid drop at higher levels. On the other hand, the low-pressure scenario shows significant influence all the way up to $6 \mathrm{~km}$.

This inverse relationship between pressure and aerosol number concentration suggests an association with the passage of cyclones, a pattern consistent with previous studies (e.g. Ito, 1989; Hara, 2004; Hara et al., 2011b). Given that the previously presented back trajectory analysis suggested an AFT source region for the aerosol, it is reasonable to suggest that cyclones provide an accelerated pathway for air-mass subsidence from the AFT to the surface where measurement occurs. The positive latitudinal correlation observed in the polar cell in $\mathrm{CN}_{3-10}$ data (Fig. 1), as well as ratio data (Appendix Fig. A6), also support this idea, reflecting the higher concentrations of smaller particles at locations closer to the continent where air masses first reach the surface. This relationship, between aerosol number concentration and transit time, could be the result of coagulational growth mechanisms that lead to increasing aerosol size, but decreasing number concentration. The longer the period of time since nucleation, the greater the time for coagulation to occur, and therefore, the lower the number of aerosols in the air mass.

\subsection{Impact on the regional atmosphere}

Given that the aerosol number concentration recorded during this voyage was markedly higher than those of any previous measurement in the region, and the circulation patterns leading to these concentrations have not previously been described, it is worth assessing the likely impact of the aerosol population on atmospheric chemistry and importantly, the radiative balance.

The natural aerosols found in the Antarctic region generally increase the planetary albedo. Above the high albedo surface of the Antarctic continent and sea ice, changes in albedo due to natural aerosols produce negligible radiative changes. If however, aerosols escape the polar cell, grow and enter the lower latitudes where a darker ocean surface is present, their albedo effects become substantial. In the Southern Ocean, where cloud fraction is consistently above 0.9 (http://neo.sci.gsfc.nasa.gov/view.php?datasetId= MODAL2_M_CLD_FR), direct scattering of incoming radiation by aerosol (the effective radiative forcing due to aerosol-radiation interaction, ERFari; IPCC, 2013) is likely to be minimal compared to the effect aerosols would have on cloud property modification (the effective radiative forcing due to aerosol-cloud interaction, ERFaci; IPCC, 2013).

Five-day forward trajectories were calculated from the ship's location to assess the spatial impact of these air masses. The resulting impact map, shown in Fig. 7, shows 

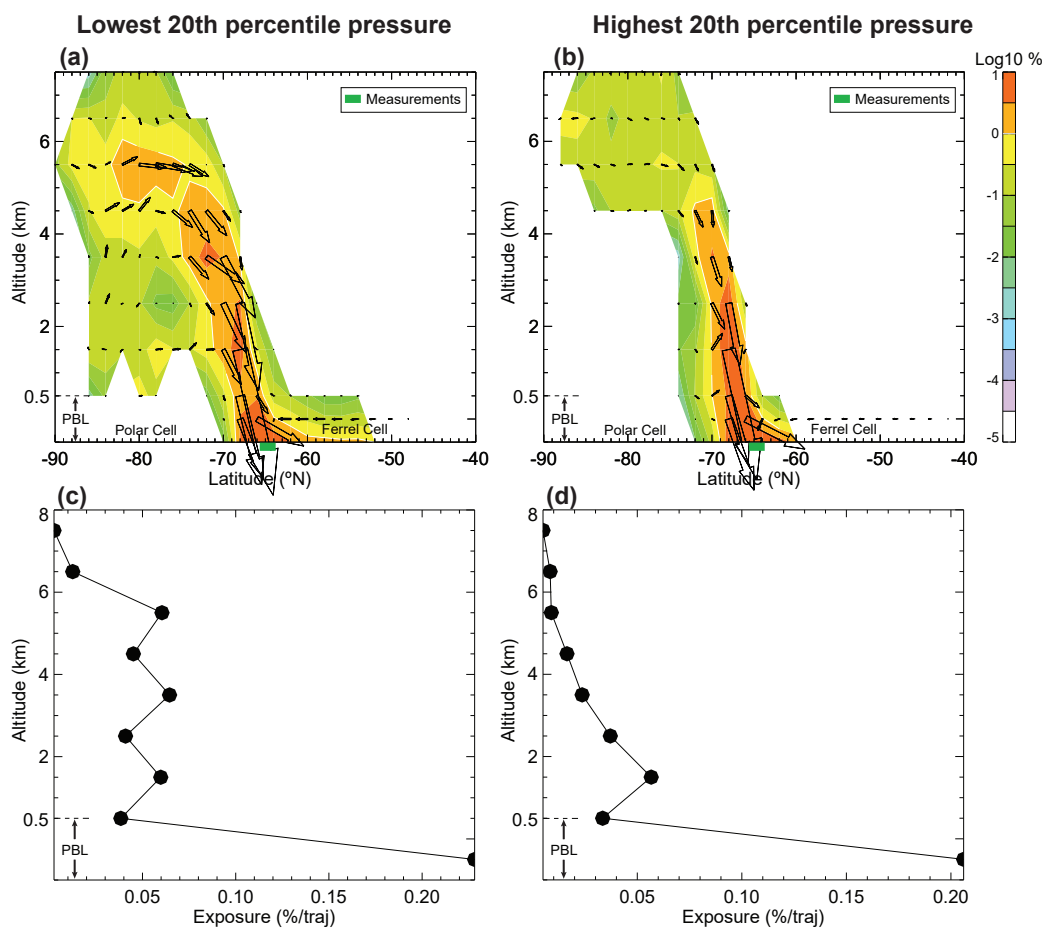

Figure 6. Analysis of 5-day back trajectories released at $10 \mathrm{~m}$ height from the marked (green) measurement location every hour of sea-ice voyage for the two different pressure scenarios: the lowest 20th percentile of pressures (a and $\mathbf{c}$ ) and the highest 20th percentile of pressures (b and d). Panels (a) and (b) are similar to Fig. 3, but show the frequency (i.e. number of times a trajectory passes through a given grid box) component, colours plotted in log scale. (c) and (d) show the exposure of the trajectories to each altitude interval. This is defined as the mean percentage of time trajectories spent in each $1 \mathrm{~km}$ layer of the atmosphere up to $8 \mathrm{~km}$. Note again the expansion of the PBL in all plots.

significant influence over the Southern Ocean, frequently north of $45^{\circ} \mathrm{S}$ within the 5-day period of the trajectories (and into the Tropics within 10-day trajectories, not shown). Further analysis found that after 5 days, over half of the air masses passing through the sea-ice region had moved above the surface layer (Fig. A5) and escaped north of the ice edge and into the Southern Ocean region where surface albedo is low (Fig. 7). By rising above the boundary layer this feature explains (a) the absence of elevated aerosol number concentrations observed in the Ferrel cell region of our data set and consequently (b) the latitudinal step change of Fig. 1. The remaining air masses not travelling north are observed to ascend in the polar front and travel south within the continental troposphere, transporting with them the aerosol populations as well as any precursors for nucleation that are emitted from the sea ice and Southern Ocean.

The equatorward air flow has the potential to transport the relatively high concentrations of aerosols from the sea-ice region over the low-albedo Southern Ocean region. Growth of freshly nucleated particles to climatically relevant sizes $(>80 \mathrm{~nm})$ has been observed in previous Antarctic studies (e.g. Virkkula et al., 2006; Koponen et al., 2003). Of the few aerosol measurements that have been made in the Southern Ocean atmosphere, there was a distinct absence of nanoparticles $\left(\mathrm{CN}_{3-10}\right)$ in the majority of observations (We- ber et al., 1999). It is likely then, that if nanoparticles are transported from the sea-ice region to the Southern Ocean region, that they grow significantly. Growth can occur via two processes: coagulation and condensation. For the latter, condensing gaseous species must be present. Given that air masses pass the highly productive sea-ice region before moving equatorward, it is reasonable to presume that they are enriched by emissions of precursor gases which have yet to be oxidised (and thus do not immediately condense), but which could contribute to growth at a later time. Although conjectural, this precursor enrichment could be sufficient for condensational growth of aerosols in the Southern Ocean atmosphere and may also contribute to new particle formation events observed at mid-latitude locations such as Cape Grim (Gras et al., 2009). Additionally, the second flow to the Antarctic troposphere (i.e. the rising polar front flow) could also transport these precursors, providing precursors for nucleation. It is important to emphasise that these ideas are only speculative and require further investigation for validation.

\section{Discussion}

The aerosol number concentrations presented in this work represent the highest background population ever observed in the Antarctic and Southern Ocean region. It is important 


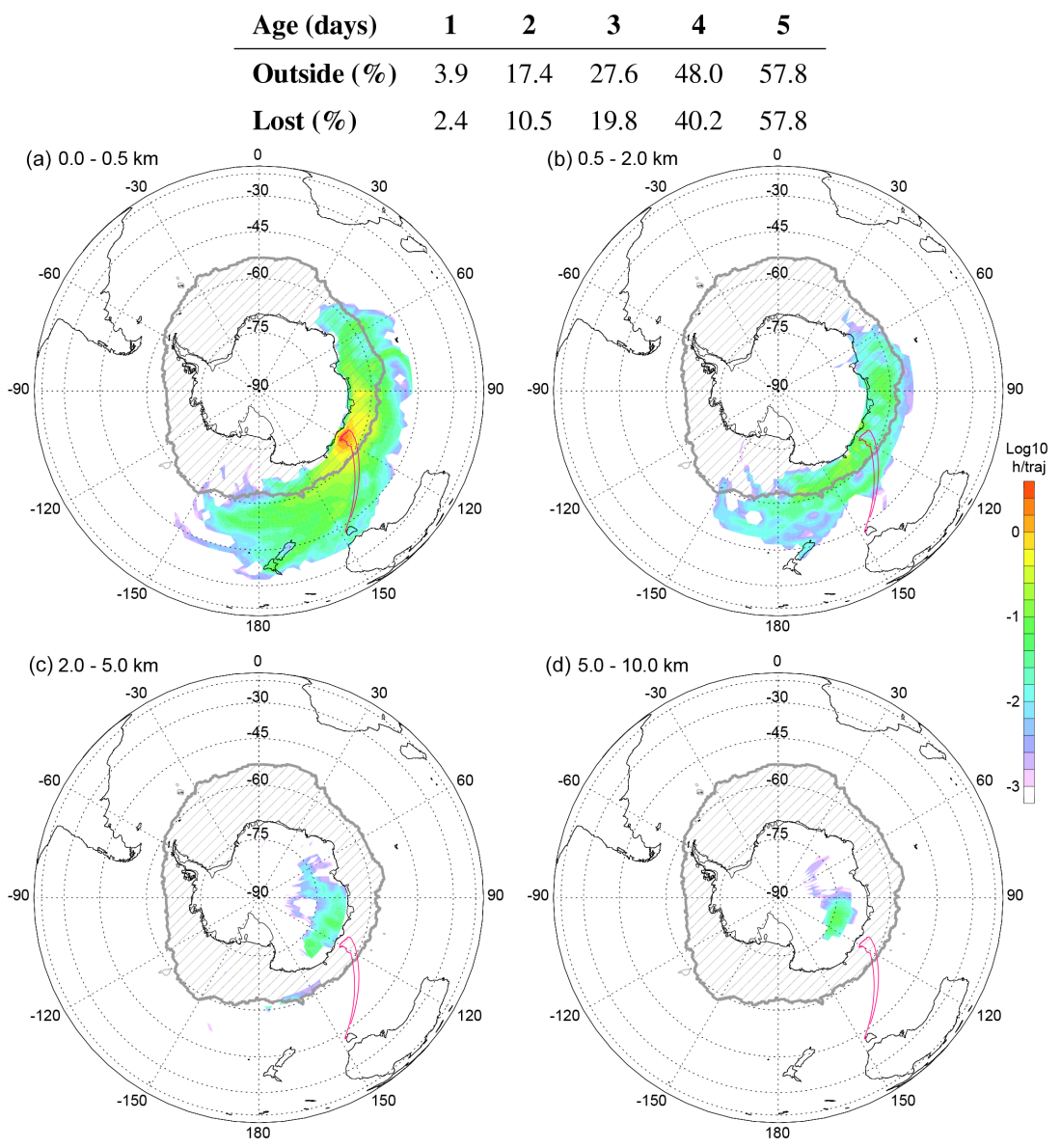

Figure 7. Five-day forward trajectories released from SIPEXII locations and times and passing through the following atmospheric layers: (a) the first $500 \mathrm{~m}$, (b) $500 \mathrm{~m}$ to $2 \mathrm{~km}$, (c) 2 to $5 \mathrm{~km}$ and (d) 5 to $10 \mathrm{~km}$. The ice edge and ship track are shown for reference, while colours reflect the percentage, in log scale, of trajectories released which pass through a given grid box. The table above classifies, as a function of days after release, the percentage of the total number of trajectories either outside (those outside the sea-ice edge on the given day) or lost (those which do not re-enter the sea-ice zone after the given number of days).

to reiterate that this assumes a conservative lower bound due to high uncertainties in inlet efficiencies at the low particle size ranges. The difficulty of characterising inlet efficiencies is common for investigations of this type and as such, is often not applied in detail. Theoretical calculations of inlet losses suggest that transmission of $\mathrm{CN}_{3-10}$ particles through the inlet could be as low as $30 \%$ (Appendix Fig. A1), which when applied to the data, could lead to an almost 3-fold increase in number concentrations in this size range. This in turn will increase the $\mathrm{CN}_{3}$ values measured here, the magnitude of which is dependent on the population's size distribution.

Aerosols and their precursors in the Antarctic region originate predominantly from marine and sea-ice areas, with only one recent study reporting aerosols sourced from local meltpond cyanobacteria (Kyrö et al., 2013). The sea-ice region experiences high biological productivity (Moore and Abbott, 2000), with products such as dimethyl sulfide (DMS) and other organic species readily available as potential precursors for particle production. The Southern Ocean itself con- tributes $62 \%$ of the global DMS flux to the atmosphere, with the highest concentrations occurring in the Antarctic sea ice (Levasseur, 2011; Bates et al., 1992; Lana et al., 2011). Previous aerosol volatility measurements in the AFT deduced that sulfate is the primary component of nanoparticle populations and speculated that biologically produced DMS is the primary precursor (e.g. Iwasaka et al., 1985; Hara et al., 2006). However, composition measurements have not been conclusive. Iodine species, which have been shown to be efficient precursors for aerosol formation (O'Dowd et al., 1998), have been measured in situ (Saiz-Lopez et al., 2007b; Frieß et al., 2001, 2010; Atkinson et al., 2012) and via satellite (SaizLopez et al., 2007a; Schönhardt et al., 2008, 2012) in significant concentrations that reveal Antarctica as a global iodine hotspot, particularly in West Antarctica during spring. A recent analysis by Roscoe et al. (2015) found that linear combinations of IO concentrations measured from satellite could reproduce the seasonal patterns of particle number concentrations measured at Halley and Neumayer during spring, 
with sulfur explaining the summer peak. Allan et al. (2015) have recently shown the involvement of iodine in aerosol nucleation in the Arctic region, suggesting that it could be important in aerosol formation in polar regions. It is possible that DMS or iodine compounds are emitted from the sea-ice and Southern Ocean regions and are transported to the AFT with the ascending polar front and contribute directly to the reservoir of precursors that back trajectories suggest may be present.

The high aerosol concentrations observed in this study were found to be correlated with the passage of cyclones, suggesting cyclonic involvement in transporting air from their likely source region in the AFT, down to the surface. If the cyclone activity is indeed the primary influence for this transport, the high aerosol concentrations observed during this voyage would be expected to be found wherever cyclones are present in the region. This is likely to be particularly true at polar cell latitudes where the uplift of the polar front would lead to a significant reservoir of precursor species available for nucleation. Cyclones are common in the Southern Ocean and Antarctic regions, with an average of 37 cyclones (with a duration of more than $24 \mathrm{~h}$ ) occurring each year in the Southern Hemisphere (Simmonds and Keay, 2000a). The average duration of the cyclones is around 3.2 days (Simmonds and Keay, 2000b), while the mean distance covered by cyclones is approximately $2000 \mathrm{~km}$ (Simmonds and Keay, 2000a). Cyclones are found to be most common in the $50-70^{\circ} \mathrm{S}$ latitudinal band directly adjacent to the coast, with this region experiencing an average of $43 \%$ of the cyclones in the Southern Hemisphere throughout the year (Simmonds and Keay, 2000a). Within this band, maxima of both cyclogenesis and cyclolysis occur south of $60^{\circ} \mathrm{S}$ (Simmonds and Keay, 2000a), suggesting significant influence within the polar cell. Given the frequency, length and spatial distribution of cyclones in this region, the influence of cyclones, and thus the potential magnitude of transport from the AFT is significant, and could extend around the continent. This suggests that the high concentrations measured during this campaign may be occurring throughout the sea-ice region, particularly in the $60-70^{\circ} \mathrm{S}$ latitudinal band where cyclone activity is strongest.

This potential band of high aerosol loading could have significant implications on the impact of aerosols on the region. If aerosol concentrations are this high in a sparsely measured latitudinal band all around the continent, then it is reasonable to suggest that the aerosol number concentrations in the Antarctic and Southern Ocean regions have previously been underestimated. This study suggests that coastal regions, as measured by most long-term atmospheric programmes, are not representative of sea-ice regions. This is true for two reasons: (1) the significantly higher aerosol number concentrations measured in this study and (2) the circulation patterns described above involve the descent of AFT air, reaching the surface just off the coast in a surprisingly well-defined form. Additionally, many of these stations are in the north- west quadrant of Antarctica (e.g. Aboa and Neumayer) which has been found to be the region where these circulation patterns are weakest (Humphries et al., 2016). If this is true, it could have significant implications for both the physics and chemistry of the atmosphere in this pristine region. However, although unlikely, it could also be possible that the measurements reported here represent only a temporary event that was fortuitously measured. Consequently, along with the continuation of the invaluable coastal research programmes, additional measurements programmes within the sea ice are crucial to understanding the region and could help reduce the large contribution to uncertainty that pre-industrial, natural aerosols contribute to the effective radiative forcing (Ghan et al., 2013; Carslaw et al., 2013).

Current state-of-the-art climate model simulations contain significant biases in the radiative balance of the oceandominated Southern Hemisphere (Trenberth and Fasullo, 2010; Mason et al., 2014). These biases are particularly strong in the latitudinal band corresponding to the Southern Ocean, and suggest that too much solar radiation is entering the oceans - a symptom of systematic deficiencies in the representation of clouds and their albedo. Aerosol measurements in the Southern Ocean are limited (e.g. Jimi et al., 2007; Bates et al., 1998) and hence our understanding of its loading and composition is uncertain. It is plausible that the combined forward transport pathways and high aerosol number concentrations observed in this work contribute to Southern Ocean CCN loading, consequently increasing the albedo by providing sufficient condensation sites needed for additional cloud formation and/or increasing the reflectivity of existing clouds - thereby minimising the shortwave radiation biases inherent in current climate simulations.

As climate change intensifies, both transport mechanisms and precursor sources have the potential to change significantly. There is still debate on both the magnitude and sign of changes that are set to occur in relation to cyclone frequency, intensity and duration (e.g. Simmonds and Keay, 2000a; Lim and Simmonds, 2007; Fyfe, 2003). The location of the polar front, an important factor in determining atmospheric boundaries, sea-ice extent, and consequently precursor emissions, is also likely to change, with climate change pushing it poleward (Seidel et al., 2008; Lucas et al., 2014; Davis and Rosenlof, 2012; Choi et al., 2014), while the recovery of the ozone hole results in an equatorward shift (Thompson et al., 2011; WMO, 2014). Recent studies of DMS emissions propose both significant increases (due to temperature) (Meskhidze and Nenes, 2006) and decreases (due to ocean acidification) (Six et al., 2013). These changes are likely to have substantial effects on the aerosol loading at the surface and the lower troposphere over the entire region, and the flow-on effect for cloud and radiative properties may be significant. 


\section{Conclusions}

This work presents measurements of $\mathrm{CN}_{3}$ and $\mathrm{CN}_{10}$ aerosol number concentrations obtained during a marine science voyage in the pack ice off the East Antarctic coast during the spring of 2012. Boundary layer $\mathrm{CN}_{3-10}$ were found to exhibit a 10-fold increase moving south across the polar front, with polar cell mean and median $\mathrm{CN}_{3}$ number concentrations of 1130 and $816 \mathrm{~cm}^{-3}$, respectively $\left(\mathrm{CN}_{10} 351\right.$ and $256 \mathrm{~cm}^{-3}$, respectively). Polar cell concentrations were markedly higher than any previous observation in the Antarctic and Southern Ocean region. Further analysis indicates that these aerosols were unlikely to have formed locally. Trajectory analyses showed significant AFT influence, suggesting it as a possible nucleation region. Transport from the AFT to the surface was also found to be enhanced by cyclone activity. Forward trajectories suggest that measured air masses travel northward into the low-albedo Southern Ocean region where their impact on the radiative balance may be significant. This work provides an important data set in a rarely measured region of the globe, and may help reduce the discrepancy currently present between models and observations in the representation of AOD and clouds over the Southern Ocean.

\section{Data availability}

Data from the voyage are available at the Australian Antarctic Data Centre (AADC). Data set DOIs will be made public upon publication. 


\section{Appendix A: 9 October}

There are two periods in the aerosol record that showed short-term $(\sim$ hours $)$ increases in number concentrations that at first glance, are indicative of local new particle formation events. The largest of these, occurring on 18 October, did prove to be a local event and this is described in detail in a separate publication (Humphries et al., 2015). The second period, occurring on 9 October, is worth a more thorough analysis here.

This event was characterised by a sharp increase in number concentrations in both size bins, and a simultaneous (albeit modest relative to the 18 October event) increase in the ratio value. Despite this significant increase in number concentrations, time delays between increases in the size bins were not existent, suggesting that no growth occurred and making local formation unlikely.

Backward trajectories were calculated to assess whether air-mass history was different during the event compared to the remaining background period. As discussed in the main text, background aerosol populations were found to be transported within air masses that had recently come from the Antarctic Free Troposphere (AFT). It is possible that after formation in the AFT, condensational growth halted, while coagulation processes continued slowly, at a rate that is not measurable with the current instrumentation. This process would slowly reduce the ratio value. In this circumstance, the more time that has elapsed since formation in the AFT, the lower the ratio value, assuming no addition of condensing species (reasonable considering the air mass is lofted from the surface). Consequently, it is possible that a temporary increase in the ratio value that occurs without any other growth indicators, such as that observed on 9 October, could be caused by an aerosol population that has been more recently formed compared to the remaining background measurements.

Figure A7 shows $36 \mathrm{~h}$ backward trajectories calculated using NOAA's HYSPLIT model. Trajectories released before the event (08:00 and 10:00 UTC) were found to be representative of the majority of the Polar cell trajectories, travelling from the east along the sea-ice surface for around $36 \mathrm{~h}$ after having descended from the AFT. The following three trajectories, chosen to end during the period of increased aerosol concentration, were found to have come from the south, and have been in the AFT less than $24 \mathrm{~h}$ before measurement. The beginning of the declining number concentrations coincided with air masses that had at least $36 \mathrm{~h}$ within the surface layer (below $500 \mathrm{~m}$ ) prior to measurement. This supports the suggestion that the enhanced aerosol population during this period was a result of more recent influence from the AFT where nucleation was likely to be occurring.

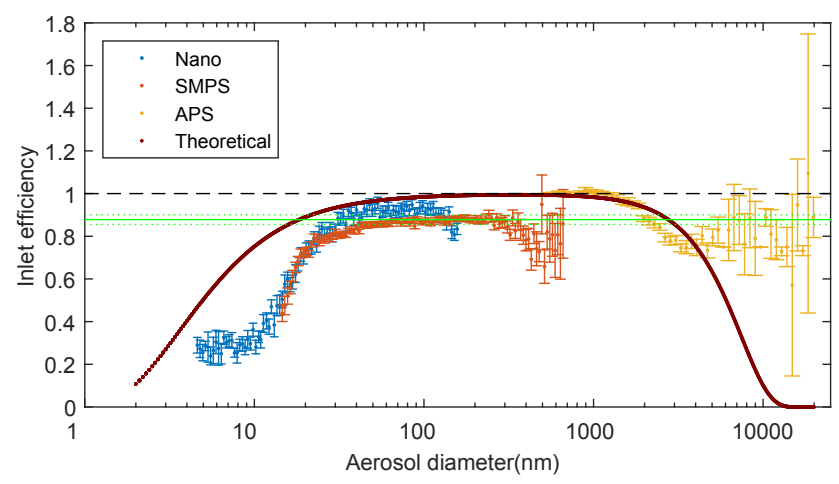

Figure A1. Median (with respect to 1000 bootstrap sub-samples) aerosol inlet efficiencies as a function of aerosol diameter (log scale) from three different instruments used to cover the size range of $4 \mathrm{~nm}-20 \mu \mathrm{m}$, together with theoretically calculated efficiencies. The three instruments used were: scanning mobility particle sizer (SMPS) for the smallest aerosol sizes (referred to as Nano), a standard size range SMPS (SMPS in legend) and an Aerodynamic Particle Sizer (APS). Error bars represent 2 standard deviations calculated from the median absolute deviation of bootstrap sub-samples. The horizontal lines represent the overall IE with calculated $2 \sigma$ error bars, with the black line a $100 \%$ efficiency reference line.

This significant drop in temperature is indicative of the temperatures one would observe in air that has recently been in the AFT at a latitude further south than measured. Figure A8 shows the inverse relationship between air temperature and aerosol number concentrations during this event, with temperatures plummeting from around $-9^{\circ} \mathrm{C}$ before and after the event, down to below $-15^{\circ} \mathrm{C}$ during the period when aerosol numbers are highest and when trajectories suggest air masses have more recently been in the AFT.

Both trajectory calculations and in situ air temperature data support the conclusion suggested from aerosol data that this significant increase in aerosol number concentrations is not the result of local new particle formation. Instead, the increased concentrations result from air masses that have more recently come from the AFT, providing less time for number concentrations to reduce from coagulational processes, and therefore leaving a higher portion of the population in the sub- $10 \mathrm{~nm}$ size range compared to the remaining background populations. 


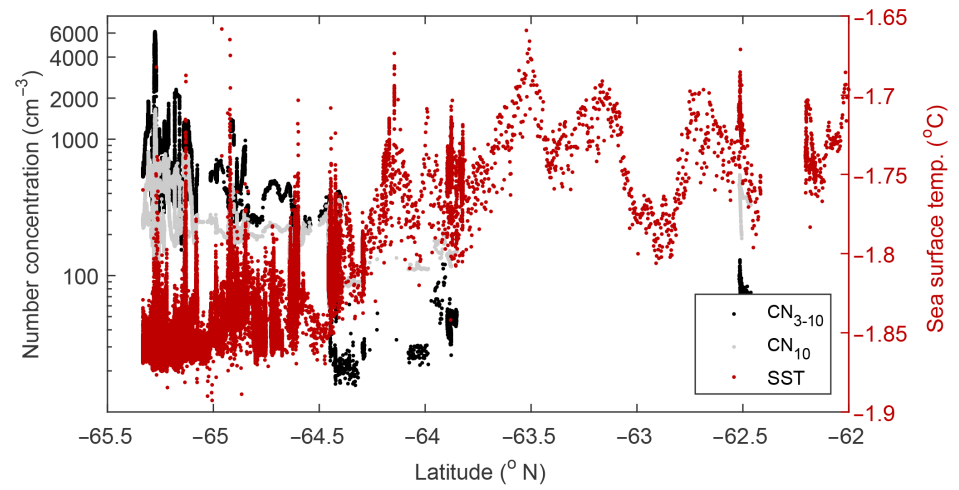

Figure A2. As in Fig. 1, but with in situ sea surface temperature measurements. Temperatures measured within the sea-ice zone, but north of the aerosol step change showed a median of $-1.75 \pm 0.02{ }^{\circ} \mathrm{C}\left( \pm\right.$ median absolute deviation) while those south were $-1.85 \pm 0.01{ }^{\circ} \mathrm{C}$.

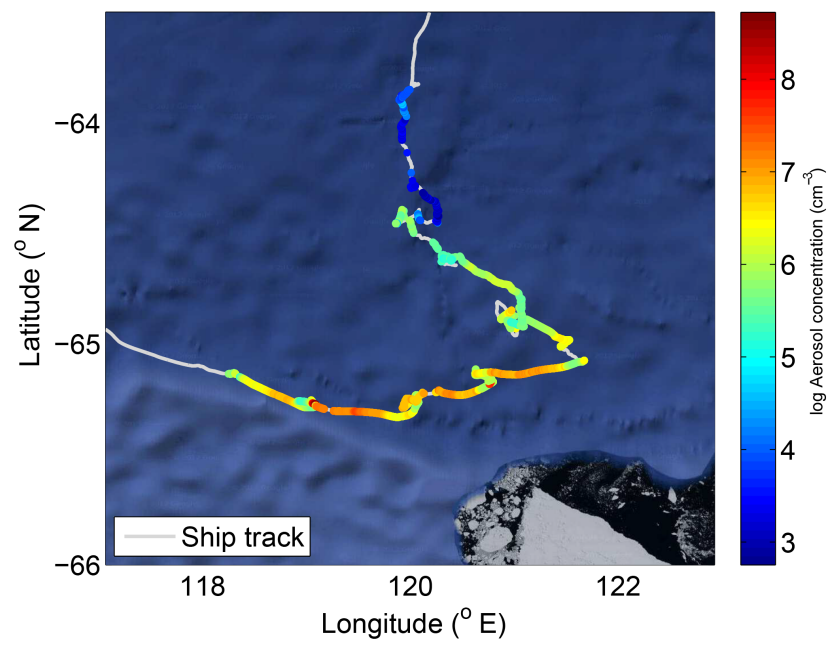

Figure A3. $\mathrm{CN}_{3-10}$ number concentrations in log scale, overlayed on the ship's track (grey line) and Google Earth satellite imagery. The step change is observed clearly around $64.4^{\circ} \mathrm{S}$, while a gradual increase can be discerned with increasing latitude within the polar cell. 

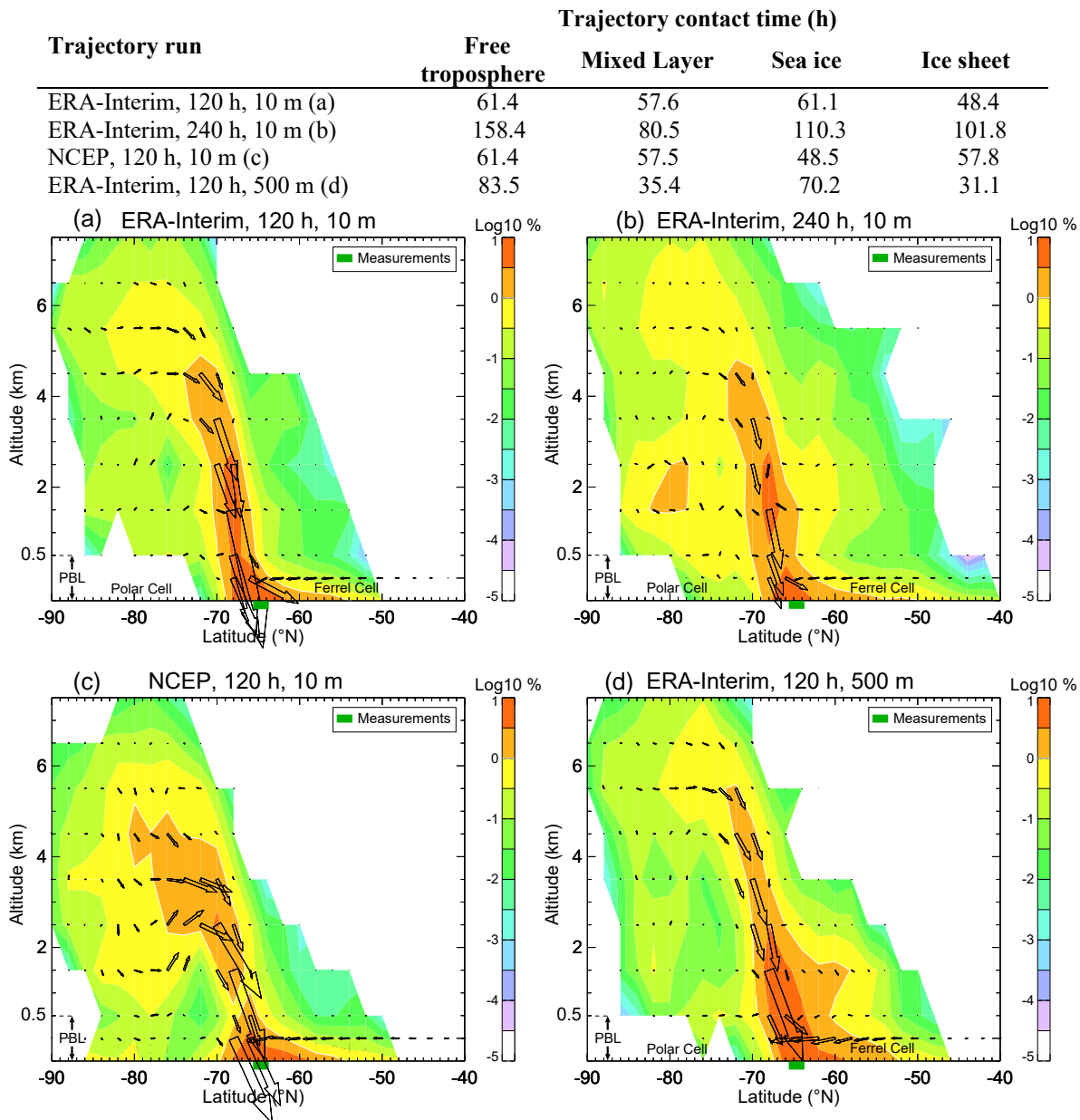

Figure A4. Assessment of reliability of trajectory analyses in the Antarctic region. (a) Longitudinally averaged cross section showing grid frequency of five day back trajectories using ERA-Interim reanalysis, released at $10 \mathrm{ma}$.s.1. for every hour of the voyage, with twodimensional vectors weighted by the number of points at each location. (b) As in (a), but for 10-day trajectories. (c) As in (a), but using NCEP reanalysis. Analyses with GDAS reanalysis produced patterns similar to ERA-Interim. (d) As in (a), but using a starting point of $500 \mathrm{~m}$. Varying any of these parameters creates minimal changes in final trajectories, giving confidence in the conclusions of circulation. The table above outlines average contact time with various aspects of the atmosphere and surface. Note that the sum of the free troposphere and mixed layer contact times does not equal the total time due to necessary data removal and rounding. 


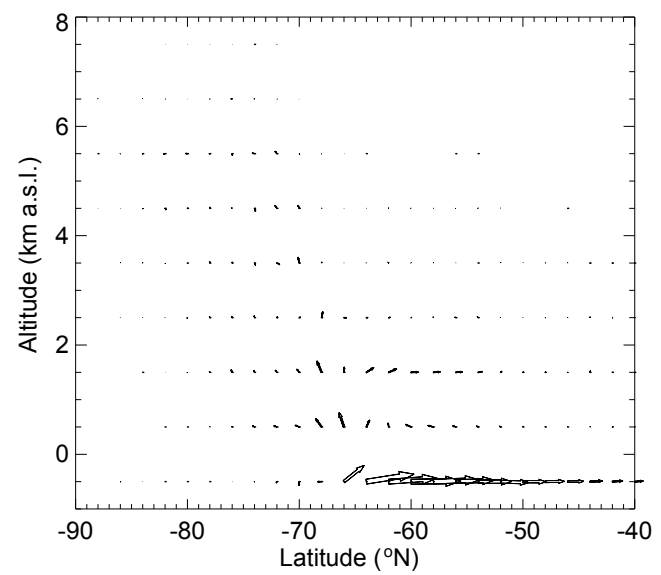

Figure A5. Two-dimensional vectors weighted by number of points at each pixel. Trajectories were calculated from the 10-day forward trajectories beginning at the ship location throughout the voyage. The rising air of the polar front is clearly visible, however the overwhelming flow is found to ascend slightly within the boundary layer, above the layer closest to the surface, then travel north.

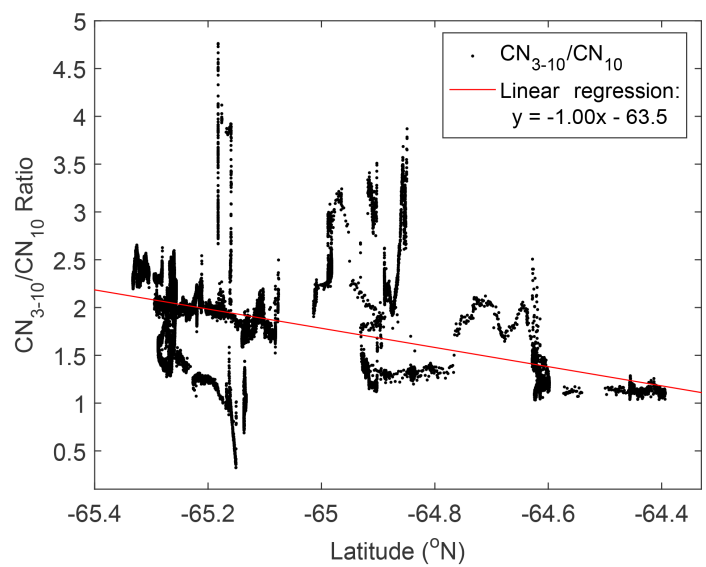

Figure A6. The ratio $\mathrm{CN}_{3-10} / \mathrm{CN}_{10}$ is shown only for polar cell latitudes. The new particle formation event on the 18 October (Humphries et al., 2015) was removed to result in a background data set. The linear regression shows a substantial increase with latitude. 
NOAA HYSPLIT MODEL

Backward trajectories ending at 2000 UTC 09 Oct 12

GDAS Meteorological Data

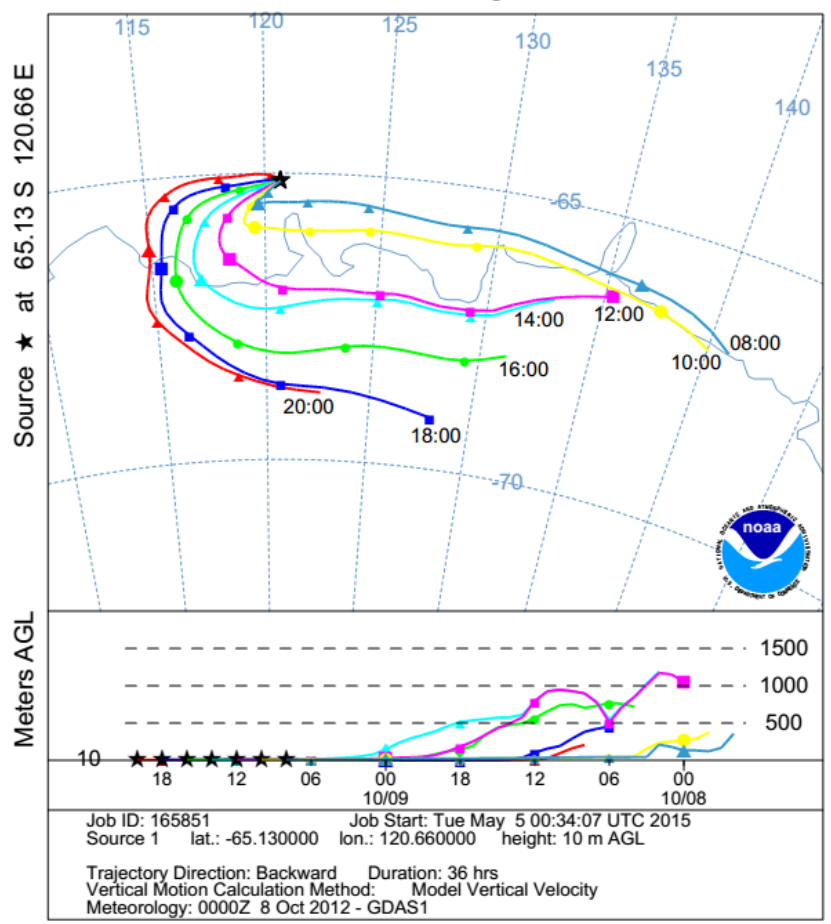

Figure A7. $36 \mathrm{~h}$ backward trajectories released every $2 \mathrm{~h}$ from the measurement location (10 ma.s.1.) and spanning the 9 October enhanced aerosol event.

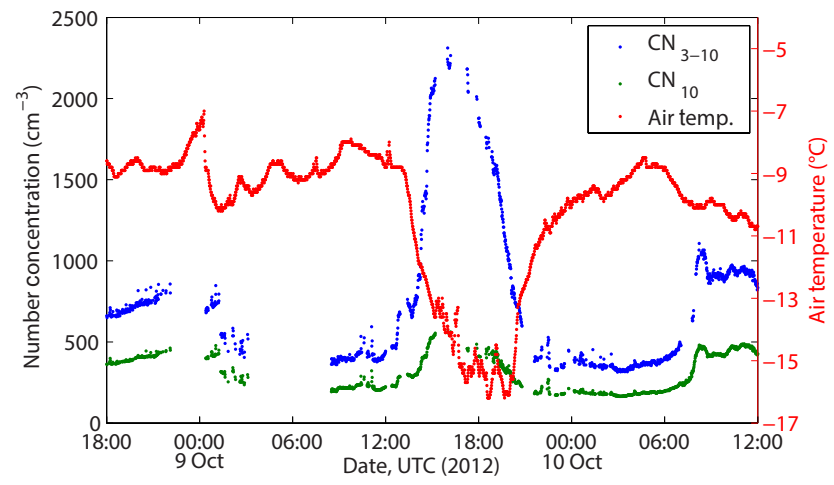

Figure A8. Air temperature and aerosol number concentrations in the two size ranges during the enhanced aerosol event of 9 October. 


\section{Appendix B: Trajectory uncertainty}

As discussed in the main text, the reliability of reanalysis data sets is a legitimate concern in any assessment of atmospheric circulation. In the Antarctic region, surface measurements are relatively sparse compared to other parts of the globe. Uncertainties in trajectory analyses magnify the longer they run, so that 10-day trajectories may not contain significantly more information that 5-day trajectories, and may in fact be misleading. Additionally, the starting locations of trajectories may affect their reliability, particularly when starting locations are within the lower boundary layer. Some trajectory models terminate when the modelled airparcel touches the surface, likely because of this high uncertainty.
The reliability of these factors was assessed by running simulations with various input reanalysis data sets, running times and starting heights. Examples of results from these studies are shown in Fig. A4. Input reanalysis data sets included ERA-Interim, Global Data Assimilation System (GDAS), and National Centers for Environmental Prediction (NCEP) reanalysis. Running times tested were 5 and 10 days, while starting heights included 10, 100, 500, then every $500 \mathrm{~m}$ up to $4 \mathrm{~km}$. It was found that inferences about average circulations patterns were insensitive to data set, starting heights and runtime, giving a reasonable level of confidence to our conclusions. 
Author contributions. R. Humphries wrote the paper, led the overall data analysis and interpretation, ran the instruments during the field campaign and performed quality control on aerosol data. A. Klekociuk performed the trajectory modelling and validation, and together with R. Humphries interpreted trajectory data. R. Schofield led AAS Project 4032, and was instrumental in the field campaign and data analysis. M. Keywood and J. Ward provided aerosol instrumentation and technical support. R. Schofield, M. Keywood and S. Wilson provided academic support. All authors contributed to the editing of the paper.

Acknowledgements. This research was funded by the Australian Antarctic Science Grant Program (AAS Project 4032). Additional support was also provided by the CSIRO OCE Postgraduate Top-Up Scholarship.

Edited by: V.-M. Kerminen

\section{References}

Allan, J. D., Williams, P. I., Najera, J., Whitehead, J. D., Flynn, M. J., Taylor, J. W., Liu, D., Darbyshire, E., Carpenter, L. J., Chance, R., Andrews, S. J., Hackenberg, S. C., and McFiggans, G.: Iodine observed in new particle formation events in the Arctic atmosphere during ACCACIA, Atmos. Chem. Phys., 15, 5599_ 5609, doi:10.5194/acp-15-5599-2015, 2015.

Asmi, E., Frey, A., Virkkula, A., Ehn, M., Manninen, H. E., Timonen, H., Tolonen-Kivimäki, O., Aurela, M., Hillamo, R., and Kulmala, M.: Hygroscopicity and chemical composition of Antarctic sub-micrometre aerosol particles and observations of new particle formation, Atmos. Chem. Phys., 10, 4253-4271, doi:10.5194/acp-10-4253-2010, 2010.

Atkinson, H. M., Huang, R.-J., Chance, R., Roscoe, H. K., Hughes, C., Davison, B., Schönhardt, A., Mahajan, A. S., Saiz-Lopez, A., Hoffmann, T., and Liss, P. S.: Iodine emissions from the sea ice of the Weddell Sea, Atmos. Chem. Phys., 12, 11229-11244, doi:10.5194/acp-12-11229-2012, 2012.

Bates, T. S., Lamb, B. K., Guenther, A., Dignon, J., and Stoiber, R. E.: Sulfur emissions to the atmosphere from natural sources, J. Atmos. Chem., 14, 315-337, doi:10.1007/bf00115242, 1992.

Bates, T. S., Huebert, B. J., Gras, J. L., Griffiths, F. B., and Durkee, P. A.: International Global Atmospheric Chemistry (IGAC) project's first Aerosol Characterization Experiment (ACE 1): overview, J. Geophys. Res., 103, 16297, doi:10.1029/97JD03741, 1998.

Belosi, F., Contini, D., Donateo, A., Santachiara, G., and Prodi, F.: Aerosol size distribution at Nansen Ice Sheet Antarctica, Atmos. Res., 107, 42-50, 2012.

Bigg, E. K., Gras, J. L., and Evans, C.: Origin of aitken particles in remote regions of the Southern Hemisphere, J. Atmos. Chem., 1, 203-214, 1983.

Brechtel, F. J., Kreidenweis, S. M., and Swan, H. B.: Air mass characteristics, aerosol particle number concentrations, and number size distributions at Macquarie Island during the First Aerosol Characterization Experiment (ACE 1), J. Geophys. Res.-Atmos., 103, 16351-16367, doi:10.1029/97jd03014, 1998.
Carslaw, K. S., Lee, L. A., Reddington, C. L., Pringle, K. J., Rap, A., Forster, P. M., Mann, G. W., Spracklen, D. V., Woodhouse, M. T., Regayre, L. A., and Pierce, J. R.: Large contribution of natural aerosols to uncertainty in indirect forcing, Nature, 503, 67-71, doi:10.1038/nature12674, 2013.

Choi, J., Son, S.-W., Lu, J., and Min, S.-K.: Further observational evidence of Hadley cell widening in the Southern Hemisphere, Geophys. Res. Lett., 41, 2590-2597, doi:10.1002/2014GL059426, 2014.

Davis, S. M. and Rosenlof, K. H.: A multidiagnostic intercomparison of tropical-width time series using reanalyses and satellite observations, J. Climate, 25, 1061-1078, doi:10.1175/JCLI-D11-00127.1, 2012.

Davison, B., Hewitt, C. N., O’Dowd, C. D., Lowe, J. A., Smith, M. H., Schwikowski, M., Baltensperger, U., and Harrison, R. M.: Dimethyl sulfide, methane sulfonic acid and physicochemical aerosol properties in Atlantic air from the United Kingdom to Halley Bay, J. Geophys. Res., 101, 22855-22867, doi:10.1029/96jd01166, 1996

Dee, D. P., Uppala, S. M., Simmons, A. J., Berrisford, P., Poli, P., Kobayashi, S., Andrae, U., Balmaseda, M. A., Balsamo, G., Bauer, P., Bechtold, P., Beljaars, A. C. M., van de Berg, L., Bidlot, J., Bormann, N., Delsol, C., Dragani, R., Fuentes, M., Geer, A. J., Haimberger, L., Healy, S. B., Hersbach, H., Hólm, E. V., Isaksen, L., Kållberg, P., Köhler, M., Matricardi, M., McNally, A. P., Monge-Sanz, B. M., Morcrette, J.-J., Park, B.K., Peubey, C., de Rosnay, P., Tavolato, C., Thépaut, J.-N., and Vitart, F.: The ERA-Interim reanalysis: configuration and performance of the data assimilation system, Q. J. Roy. Meteor. Soc., 137, 553-597, doi:10.1002/qj.828, 2011.

Dong, S., Sprintall, J., and Gille, S. T.: Location of the Antarctic polar front from AMSR-E satellite sea surface temperature measurements, J. Phys. Oceanogr., 36, 2075-2089, doi:10.1175/JPO2973.1, 2006.

Draxler, R. R. and Hess, G. D.: An overview of the HYSPLIT_4 modelling system for trajectories, dispersion, and deposition, Aust. Meteorol. Mag., 47, 295-308, 1998.

Frieß, U., Wagner, T., Pundt, I., Pfeilsticker, K., and Platt, U.: Spectroscopic measurements of tropospheric iodine oxide at Neumayer Station, Antarctica, Geophys. Res. Lett., 28, 1941-1944, doi:10.1029/2000g1012784, 2001.

Frieß, U., Deutschmann, T., Gilfedder, B. S., Weller, R., and Platt, U.: Iodine monoxide in the Antarctic snowpack, Atmos. Chem. Phys., 10, 2439-2456, doi:10.5194/acp-10-2439-2010, 2010.

Fyfe, J. C.: Extratropical Southern Hemisphere cyclones: harbingers of climate change?, J. Climate, 16, 2802-2805, doi:10.1175/1520-0442(2003)016<2802:ESHCHO > 2.0.CO;2, 2003.

Ghan, S. J., Smith, S. J., Wang, M., Zhang, K., Pringle, K., Carslaw, K., Pierce, J., Bauer, S., and Adams, P.: A simple model of global aerosol indirect effects, J. Geophys. Res.-Atmos., 118, 6688-6707, doi:10.1002/jgrd.50567, 2013.

Gras, J. L., Jimi, S. I., Siems, S. T., and Krummel, P. B.: Postfrontal nanoparticles at Cape Grim: observations, Environ. Chem., 6, 508-514, doi:10.1071/EN09075, 2009.

Hansen, G., Aspmo, K., Berg, T., Edvardsen, K. R., Fiebig, M., Kallenborn, R., Krognes, T., Lunder, C., Stebel, K., Schmidbauer, N., Solberg, S., and Yttri, K. E.: Atmospheric monitoring at the Norwegian Antarctic station Troll: measure- 
ment programme and first results, Polar Res., 28, 353-363, doi:10.3402/polar.v28i3.6142, 2009.

Hara, K.: Chemistry of sea-salt particles and inorganic halogen species in Antarctic regions: compositional differences between coastal and inland stations, J. Geophys. Res., 109, D20208, doi:10.1029/2004JD004713, 2004.

Hara, K., Iwasaka, Y., Wada, M., Ihara, T., Shiba, H., Osada, K., and Yamanouchi, T.: Aerosol constituents and their spatial distribution in the free troposphere of coastal Antarctic regions, J. Geophys. Res., 111, D15216, doi:10.1029/2005JD006591, 2006.

Hara, K., Osada, K., Nishita-Hara, C., Yabuki, M., Hayashi, M., Yamanouchi, T., Wada, M., and Shiobara, M.: Seasonal features of ultrafine particle volatility in the coastal Antarctic troposphere, Atmos. Chem. Phys., 11, 9803-9812, doi:10.5194/acp-11-98032011, 2011a.

Hara, K., Osada, K., Nishita-Hara, C., and Yamanouchi, T.: Seasonal variations and vertical features of aerosol particles in the Antarctic troposphere, Atmos. Chem. Phys., 11, 5471-5484, doi:10.5194/acp-11-5471-2011, 2011 b.

Helsen, M. M., van de Wal, R. S. W., van den Broeke, M. R., Masson-Delmotte, V., Meijer, H. A. J., Scheele, M. P., and Werner, M.: Modeling the isotopic composition of Antarctic snow using backward trajectories: simulation of snow pit records, J. Geophys. Res., 111, D15109, doi:10.1029/2005JD006524, 2006.

Humphries, R.: Aerosol formation in the Antarctic Sea-Ice Region, Doctor of Philosophy thesis, School of Chemistry, University of Wollongong, available at: http://ro.uow.edu.au/theses/4536/ (last access: 31 January 2015), 2015.

Humphries, R., Wilson, S., Keywood, M., Ward, J., and Schofield, R.: In-situ total aerosol number using condensation particle counters as observed during the SIPEX II voyage of the Aurora Australis, 2012, doi:10.4225/15/5342423241BE4, 2014.

Humphries, R. S., Schofield, R., Keywood, M. D., Ward, J., Pierce, J. R., Gionfriddo, C. M., Tate, M. T., Krabbenhoft, D. P., Galbally, I. E., Molloy, S. B., Klekociuk, A. R., Johnston, P. V., Kreher, K., Thomas, A. J., Robinson, A. D., Harris, N. R. P., Johnson, R., and Wilson, S. R.: Boundary layer new particle formation over East Antarctic sea ice - possible Hg-driven nucleation?, Atmos. Chem. Phys., 15, 13339-13364, doi:10.5194/acp15-13339-2015, 2015.

Humphries, R., Klekociuk, A., Schofield, R., Alexander, S. P., Keywood, M., and Wilson, S.: Characterising atmospheric transport in Antarctica and the Southern Ocean using HYSPLIT, in preparation, 2016.

IPCC: Climate Change 2013: The Physical Science Basis, Contribution of Working Group I to the Fifth Assessment Report of the Intergovernmental Panel on Climate Change, Cambridge University Press, Cambridge, UK, New York, NY, USA, doi:10.1017/CBO9781107415324, 2013.

Ito, T.: Antarctic submicron aerosols and long-range transport of pollutants, Ambio, 18, 34-41, 1989.

Ito, T.: Size distribution of Antarctic submicron aerosols, Tellus B, 45, 145-159, 1993.

Ito, T.: Nature and origin of Antarctic submicron aerosols, NATO Asi. Ser. Ser. I, 30, 23-38, 1995.

Ito, T., Morita, Y., and Iwasaka, Y.: Balloon observation of aerosols in the antarctic troposphere and stratosphere, Tellus B, 38, 214 222, doi:10.3402/tellusb.v38i3-4.15130, 1986.
Iwasaka, Y., Okada, K., and Ono, A.: Individual aerosol particles in the Antarctic uper troposphere, in: Memoirs of National Institute of Polar Research, 39, 17-29, available at: http://ci.nii.ac.jp/naid/ 110000010056/en/ (last access: 22 October 2015), 1985.

Järvinen, E., Virkkula, A., Nieminen, T., Aalto, P. P., Asmi, E., Lanconelli, C., Busetto, M., Lupi, A., Schioppo, R., Vitale, V., Mazzola, M., Petäjä, T., Kerminen, V.-M., and Kulmala, M.: Seasonal cycle and modal structure of particle number size distribution at Dome C, Antarctica, Atmos. Chem. Phys., 13, 7473-7487, doi:10.5194/acp-13-7473-2013, 2013.

Jimi, S. I., Gras, J., Siems, S. T., and Krummel, P. B.: A short climatology of nanoparticles at the Cape Grim Baseline Air Pollution Station, Tasmania, Environ. Chem., 4, 301-309, 2007.

Kanamitsu, M.: Description of the NMC Global Data Assimilation and Forecast System, Weather Forecast., 4, 335-342, doi:10.1175/1520-0434(1989)004<0335:DOTNGD>2.0.CO;2, 1989.

Kistler, R., Kalnay, E., Collins, W., Saha, S., White, G., Woollen, J., Chelliah, M., Ebisuzaki, W., Kanamitsu, M., Kousky, V., van den Dool, H., Jenne, R., and Fiorino, M.: The NCEP-NCAR 50-year reanalysis: monthly means CD-ROM and documentation, B. Am. Meteorol. Soc., 82, 247-267, 2001.

Koponen, I. K., Virkkula, A., Hillamo, R., and Kerminen, V.-M.: Number size distributions and concentrations of marine aerosols: Observations during a cruise between the English Channel and the coast of Antarctica, J. Geophys. Res.-Atmos., 107, 4753, doi:10.1029/2002JD002533, 2002

Koponen, I. K., Virkkula, A., Hillamo, R., Kerminen, V.-M., and Kulmala, M.: Number size distributions and concentrations of the continental summer aerosols in Queen Maud Land, Antarctica, J. Geophys. Res.-Atmos., 108, 4587, doi:10.1029/2003jd003614, 2003.

Kottmeier, C. and Fay, B.: Trajectories in the Antarctic lower troposphere, J. Geophys. Res., 103, 10947, doi:10.1029/97JD00768, 1998.

Kulmala, M., Petäjä, T., Nieminen, T., Sipilä, M., Manninen, H. E., Lehtipalo, K., Dal Maso, M., Aalto, P. P., Junninen, H., Paasonen, P., Riipinen, I., Lehtinen, K. E. J., Laaksonen, A., and Kerminen, V.-M.: Measurement of the nucleation of atmospheric aerosol particles, Nat. Protoc., 7, 1651-1667, doi:10.1038/nprot.2012.091, 2012.

Kyrö, E.-M., Kerminen, V.-M., Virkkula, A., Dal Maso, M., Parshintsev, J., Ruíz-Jimenez, J., Forsström, L., Manninen, H. E., Riekkola, M.-L., Heinonen, P., and Kulmala, M.: Antarctic new particle formation from continental biogenic precursors, Atmos. Chem. Phys., 13, 3527-3546, doi:10.5194/acp-13-3527-2013, 2013.

Lana, A., Bell, T. G., Simó, R., Vallina, S. M., BallabreraPoy, J., Kettle, A. J., Dachs, J., Bopp, L., Saltzman, E. S., Stefels, J., Johnson, J. E., and Liss, P. S.: An updated climatology of surface dimethlysulfide concentrations and emission fluxes in the global ocean, Global Biogeochem. Cy., 25, GB1004, doi:10.1029/2010gb003850, 2011.

Levasseur, M.: Ocean science: if Gaia could talk, Nat. Geosci., 4, 351-352, doi:10.1038/ngeo1175, 2011.

Lim, E.-P. and Simmonds, I.: Southern Hemisphere winter extratropical cyclone characteristics and vertical organization observed with the ERA-40 Data in 1979-2001, J. Climate, 20, 2675-2690, doi:10.1175/JCLI4135.1, 2007. 
Lucas, C., Timbal, B., and Nguyen, H.: The expanding tropics: a critical assessment of the observational and modeling studies, Wiley Interdisciplinary Reviews: Climate Change, 5, 89-112, doi:10.1002/wcc.251, 2014.

Mason, S., Jakob, C., Protat, A., and Delanoë, J.: Characterizing observed midtopped cloud regimes associated with Southern Ocean shortwave radiation biases, J. Climate, 27, 6189-6203, doi:10.1175/JCLI-D-14-00139.1, 2014.

Meskhidze, N. and Nenes, A.: Phytoplankton and cloudiness in the Southern Ocean, Science, 314, 1419-1423, doi:10.1126/science.1131779, 2006.

Moore, J. K. and Abbott, M. R.: Phytoplankton chlorophyll distributions and primary production in the Southern Ocean, J. Geophys. Res.-Oceans, 105, 28709-28722, doi:10.1029/1999jc000043, 2000.

O’Dowd, C. D., Lowe, J. A., Smith, M. H., Davison, B., Hewitt, C. N., and Harrison, R. M.: Biogenic sulphur emissions and inferred non-sea-salt-sulphate cloud condensation nuclei in and around Antarctica, J. Geophys. Res.-Atmos., 102, 12839-12854, doi:10.1029/96jd02749, 1997.

O'Dowd, C. D., Geever, M., Hill, M. K., Smith, M. H., and Jennings, S. G.: New particle formation: Nucleation rates and spatial scales in the clean marine coastal environment, Geophys. Res. Lett., 25, 1661-1664, doi:10.1029/98GL01005, 1998.

Osada, K., Hara, K., Wada, M., Yamanouchi, T., and Matsunaga, K.: Lower tropospheric vertical distribution of aerosol particles over Syowa Station, Antarctica from spring to summer 2004, Polar Meteorology and Glaciology, 20, 16-27, 2006.

Park, J., Sakurai, H., Vollmers, K., and McMurry, P. H.: Aerosol size distributions measured at the South Pole during ISCAT, Atmos. Environ., 38, 5493-5500, 2004.

Pierce, J. R. and Adams, P. J.: Global evaluation of CCN formation by direct emission of sea salt and growth of ultrafine sea salt, J. Geophys. Res., 111, D06203, doi:10.1029/2005JD006186, 2006.

Quinn, P. K., Coffman, D. J., Kapustin, V. N., Bates, T. S., and Covert, D. S.: Aerosol optical properties in the marine boundary layer during the First Aerosol Characterization Experiment (ACE 1) and the underlying chemical and physical aerosol properties, J. Geophys. Res., 103, 16547, doi:10.1029/97JD02345, 1998.

Reeve, J.: Aurora Australis Voyage VMS 2012/13 Track and Underway Data (SIPEX II), Australian Antarctic Data Centre, doi:10.4225/15/546580A408D97, 2013.

Roscoe, H. K., Jones, A. E., Brough, N., Weller, R., SaizLopez, A., Mahajan, A. S., Schoenhardt, A., Burrows, J. P., and Fleming, Z. L.: Particles and iodine compounds in coastal Antarctica, J. Geophys. Res.-Atmos., 120, 7144-7156, doi:10.1002/2015JD023301, 2015.

Saiz-Lopez, A., Chance, K., Liu, X., Kurosu, T. P., and Sander, S. P.: First observations of iodine oxide from space, Geophys. Res. Lett., 34, L12812, doi:10.1029/2007g1030111, 2007a.

Saiz-Lopez, A., Mahajan, A. S., Salmon, R. A., Bauguitte, S. J. B., Jones, A. E., Roscoe, H. K., and Plane, J. M. C.: Boundary layer halogens in coastal Antarctica, Science, 317, 348-351, doi:10.1126/science.1141408, 2007b.

Schofield, R. and Klekociuk, A.: Hysplit atmospheric backtrajectories at $10 \mathrm{~m}, 500 \mathrm{~m}, 1000 \mathrm{~m}, 1500 \mathrm{~m}, 2000 \mathrm{~m}, 2500 \mathrm{~m}$, $3000 \mathrm{~m}, 3500 \mathrm{~m}, 4000 \mathrm{~m}$ collected during the SIPEX II voyage of the Aurora Australis, 2012, doi:10.4225/15/532F83302FF88, 2014.
Schofield, R., Klekociuk, A., Galbally, I., Molloy, S., and Humphries, R.: In-situ atmospheric ozone measurements observed during the SIPEX II voyage of the Aurora Australis, 2012, doi:10.4225/15/53266BE438281, 2014.

Schönhardt, A., Richter, A., Wittrock, F., Kirk, H., Oetjen, H. Roscoe, H. K., and Burrows, J. P.: Observations of iodine monoxide columns from satellite, Atmos. Chem. Phys., 8, 637-653, doi:10.5194/acp-8-637-2008, 2008.

Schönhardt, A., Begoin, M., Richter, A., Wittrock, F., Kaleschke, L., Gómez Martín, J. C., and Burrows, J. P.: Simultaneous satellite observations of IO and BrO over Antarctica, Atmos. Chem. Phys., 12, 6565-6580, doi:10.5194/acp-12-6565-2012, 2012.

Seidel, D. J., Fu, Q., Randel, W. J., and Reichler, T. J.: Widening of the tropical belt in a changing climate, Nat. Geosci., 1, 21-24, doi:10.1038/ngeo.2007.38, 2008.

Shindell, D. T., Lamarque, J.-F., Schulz, M., Flanner, M., Jiao, C., Chin, M., Young, P. J., Lee, Y. H., Rotstayn, L., Mahowald, N., Milly, G., Faluvegi, G., Balkanski, Y., Collins, W. J., Conley, A. J., Dalsoren, S., Easter, R., Ghan, S., Horowitz, L., Liu, X., Myhre, G., Nagashima, T., Naik, V., Rumbold, S. T., Skeie, R., Sudo, K., Szopa, S., Takemura, T., Voulgarakis, A., Yoon, J.-H., and Lo, F.: Radiative forcing in the ACCMIP historical and future climate simulations, Atmos. Chem. Phys., 13, 2939-2974, doi:10.5194/acp-13-2939-2013, 2013.

Simmonds, I. and Keay, K.: Mean Southern Hemisphere extratropical cyclone behavior in the 40-year NCEP-NCAR reanalysis, J. Climate, 13, 873-885, doi:10.1175/15200442(2000)013<0873:MSHECB>2.0.CO;2, 2000a.

Simmonds, I. and Keay, K.: Variability of Southern Hemisphere extratropical cyclone behavior, 1958-97, J. Climate, 13, 550-561, doi:10.1175/1520-0442(2000)013<0550:VOSHEC>2.0.CO;2, $2000 \mathrm{~b}$.

Six, K. D., Kloster, S., Ilyina, T., Archer, S. D., Zhang, K., and Maier-Reimer, E.: Global warming amplified by reduced sulphur fluxes as a result of ocean acidification, Nature Clim. Change,, 3, 975-978, doi:10.1038/nclimate1981, 2013.

Stohl, A. and Sodemann, H.: Characteristics of atmospheric transport into the Antarctic troposphere, J. Geophys. Res., 115, D02305, doi:10.1029/2009jd012536, 2010.

Thompson, D. W. J., Solomon, S., Kushner, P. J., England, M. H., Grise, K. M., and Karoly, D. J.: Signatures of the Antarctic ozone hole in Southern Hemisphere surface climate change, Nat. Geosci., 4, 741-749, doi:10.1038/ngeo1296, 2011.

Trenberth, K. E. and Fasullo, J. T.: Simulation of present-day and twenty-first-century energy budgets of the southern oceans, J. Climate, 23, 440-454, doi:10.1175/2009JCLI3152.1, 2010.

Virkkula, A., Teinilä, K., Hillamo, R., Kerminen, V.-M., Saarikoski, S., Aurela, M., Koponen, I. K., and Kulmala, M.: Chemical size distributions of boundary layer aerosol over the Atlantic Ocean and at an Antarctic site, J. Geophys. Res., 111, D05306, doi:10.1029/2004JD004958, 2006.

Virkkula, A., Asmi, E., Teinilä, K., Frey, A., Aurela, M., Timonen, H., Mäkelä, T., Samuli, A., Hillamo, R., Aalto, P. P., Kirkwood, S., and Kulmala, M.: Review of aerosol research at the Finnish Antarctic Research Station Aboa and its surroundings in Queen Maud Land, Antarctica, Geophysica, 45, 163-181, 2009. von der Weiden, S.-L., Drewnick, F., and Borrmann, S.: Particle Loss Calculator - a new software tool for the assessment of the 
performance of aerosol inlet systems, Atmos. Meas. Tech., 2, 479-494, doi:10.5194/amt-2-479-2009, 2009.

Warren, D. R. and Seinfeld, J. H.: Prediction of aerosol concentrations resulting from a burst of nucleation, J. Colloid Interf. Sci., 105, 136-142, doi:10.1016/0021-9797(85)90356-X, 1985.

Weber, R. J., McMurry, P. H., Bates, T. S., Clarke, A. D., Covert, D. S., Brechtel, F. J., and Kok, G. L.: Intercomparison of airborne and surface-based measurements of condensation nuclei in the remote marine troposphere during ACE 1, J. Geophys. Res.-Atmos., 104, 21673-21683, doi:10.1029/1998jd100103, 1999.

Weller, R., Minikin, A., Wagenbach, D., and Dreiling, V.: Characterization of the inter-annual, seasonal, and diurnal variations of condensation particle concentrations at Neumayer, Antarctica, Atmos. Chem. Phys., 11, 13243-13257, doi:10.5194/acp11-13243-2011, 2011.
Wiedensohlet, A., Orsini, D., Covert, D. S., Coffmann, D., Cantrell, W., Havlicek, M., Brechtel, F. J., Russell, L. M., Weber, R. J., Gras, J., Hudson, J. G., and Litchy, M.: Intercomparison study of the size-dependent counting efficiency of 26 condensation particle counters, Aerosol Sci. Tech., 27, 224-242, doi:10.1080/02786829708965469, 1997.

WMO (World Meteorological Organization): Scientific Assessment of Ozone Depletion: 2014, Tech. rep., Geneva, Switzerland, 2014. 